\title{
Secondary Metabolites of the Genus Amycolatopsis: Structures, Bioactivities and Biosynthesis
}

\author{
Zhiqiang Song, Tangchang Xu, Junfei Wang, Yage Hou, Chuansheng Liu, Sisi Liu and Shaohua Wu *D \\ Yunnan Institute of Microbiology, School of Life Sciences, Yunnan University, Kunming 650091, China; \\ songzhiqiang@mail.ynu.edu.cn (Z.S.); xu2950129@163.com (T.X.); wang_junfei@163.com (J.W.); \\ houyage@126.com (Y.H.); liucs313@126.com (C.L.); liusisi1994@126.com (S.L.) \\ * Correspondence: shhwu@ynu.edu.cn
}

\begin{abstract}
Actinomycetes are regarded as important sources for the generation of various bioactive secondary metabolites with rich chemical and bioactive diversities. Amycolatopsis falls under the rare actinomycete genus with the potential to produce antibiotics. In this review, all literatures were searched in the Web of Science, Google Scholar and PubMed up to March 2021. The keywords used in the search strategy were "Amycolatopsis", "secondary metabolite", "new or novel compound", "bioactivity", "biosynthetic pathway" and "derivatives". The objective in this review is to summarize the chemical structures and biological activities of secondary metabolites from the genus Amycolatopsis. A total of 159 compounds derived from 8 known and 18 unidentified species are summarized in this paper. These secondary metabolites are mainly categorized into polyphenols, linear polyketides, macrolides, macrolactams, thiazolyl peptides, cyclic peptides, glycopeptides, amide and amino derivatives, glycoside derivatives, enediyne derivatives and sesquiterpenes. Meanwhile, they mainly showed unique antimicrobial, anti-cancer, antioxidant, anti-hyperglycemic, and enzyme inhibition activities. In addition, the biosynthetic pathways of several potent bioactive compounds and derivatives are included and the prospect of the chemical substances obtained from Amycolatopsis is also discussed to provide ideas for their implementation in the field of therapeutics and drug discovery.
\end{abstract}

Keywords: Actinomycetes; Amycolatopsis; antibiotics; natural products; chemical structures; biological activities; biosynthetic pathways

\section{Introduction}

Antibiotics produced by microorganisms have made a significant contribution to human health. Among them, Actinomycetes are the most important sources for drug lead compounds. However, researchers have been turned to rare Actinomycetes to develop novel antibiotics with the emergence of multidrug-resistant bacteria [1]. In 1986, Lechevalier et al. defined Amycolatopsis as a new genus to accommodate nocardioform Actinomycetes having type IV cell wall composition and lacking mycolic acids [2]. Up to now, by searching in the List of Prokaryotic names with Standing in Nomenclature website (http:/ / www. bacterio.net, accessed on 20 September 2020), this genus covered 94 verified species and 4 subspecies, and forms a unique branch in the evolutionary tree of Pseudonocardiaceae. Among 26 species covered in this review, most of them colonize in a wide variety of soil and a few species survival in terrestrial (insect, lichen, island, plant) and marine (sponge, sediment) environment. The various habitats allow Amycolatopsis to produce abundant secondary metabolites.

The genus Amycolatopsis is regarded as an important source of diverse valuable bioactive natural products covering many antibiotics [3]. The most notable antibiotics produced by Amycolatopsis strains include rifamycin [4] and vancomycin [5]. In the early 1950s, vancomycin had been first extracted from Amycolatopsis orientalis that was originally regarded as Streptomyces orientalis [6]. Vancomycin was introduced for clinical use in 1958 and 
sparsely used during the first 30 years of its introduction, due to its fewer advantages over semisynthetic antibiotics like penicillin, cephalosporin, lincomycin, and fluoroquinolones. Later, the complex chemical structure of vancomycin was ultimately described in 1983 [7]. The genes of OxyB, OxyA and OxyC, encoding three cytochrome P450 enzymes, have been proven to play an important role in three aromatic cross-links of vancomycin in that order [8]. The discovery of X-domain demonstrated the role of OxyA and OxyB, which introduce bisaryl ether linkages with the help of X-domain; however, the mechanism of final crosslink of the biaryl bond installed by OxyC has not been found yet [9]. In 1959, rifamycin was isolated from Amycolatopsis mediterranei, which was the first group of antimicrobials targeting RNA polymerase. The genes of RifZ and RifQ were crucial regulatory factors of rifamycin biosynthesis. RifZ directly regulated transcription of all operons within the rifamycin biosynthesis gene cluster [10]. RifQ inhibited the export of rifamycin B and inactivating it could increase the yield of rifamycin B without affecting the growth of the A. mediterranei [11]. The understanding of metabolite biosynthesis is helpful to the rational operation of biosynthetic pathways, so as to achieve the goal of producing new natural antibiotics. At present, there are few studies on the biosynthesis of other secondary metabolites of Amycolatopsis [12]. We believe that outstanding bioactive compounds from Amycolatopsis deserve to be further researched on the mechanism of action, biosynthesis and regulatory genes. Some Amycolatopsis species have also been demonstrated to possess great potential in degrading plastics, treating heavy metals, and biotransformation. Herein, we describe a detailed summary about the chemical structures and bioactivities of secondary metabolites from Amycolatopsis reported during 1990-2020 by searching in the Web of Science, Google Scholar and PubMed. In addition, the biosynthetic pathways of several potent bioactive compounds and the derivatives of secondary metabolites via chemical synthesis, semi-synthesis and biosynthesis are also described in this paper.

\section{Secondary Metabolites from the Genus Amycolatopsis}

Secondary metabolites from Amycolatopsis are classified into polyphenols, linear polyketides, macrolides, macrolactams, thiazolyl peptides, cyclic peptides, glycopeptides, amide and amino derivatives, glycoside derivatives, enediyne derivatives and sesquiterpenes, which are all shown in Table 1.

Table 1. Secondary metabolites with sources, CAS registry numbers, and habitats from the genus Amycolatopsis during 1990-2020.

\begin{tabular}{|c|c|c|c|c|c|}
\hline Structure Types & Compounds & Sources & $\begin{array}{l}\text { CAS Registry } \\
\text { Numbers }\end{array}$ & $\begin{array}{l}\text { Habitats } \\
\left(T / M^{b}\right)\end{array}$ & Refs. \\
\hline \multirow[t]{9}{*}{ Polyphenols } & Kigamicin A (1) & $\begin{array}{l}\text { Amycolatopsis sp. } \\
\text { ML630-mF1 }\end{array}$ & $680571-49-7$ & Soil (T) & [13] \\
\hline & Kigamicin B (2) & $\begin{array}{l}\text { Amycolatopsis sp. } \\
\text { ML630-mF1 }\end{array}$ & $680571-50-0$ & Soil (T) & [13] \\
\hline & Kigamicin C (3) & $\begin{array}{l}\text { Amycolatopsis sp. } \\
\text { ML630-mF1 }\end{array}$ & 680571-51-1 & Soil (T) & [13] \\
\hline & Kigamicin D (4) & $\begin{array}{l}\text { Amycolatopsis sp. } \\
\text { ML630-mF1 }\end{array}$ & $680571-52-2$ & Soil (T) & [13] \\
\hline & Kigamicin E (5) & $\begin{array}{l}\text { Amycolatopsis sp. } \\
\text { ML630-mF1 }\end{array}$ & 680571-53-3 & Soil (T) & [13] \\
\hline & Amexanthomycin A (6) & $\begin{array}{c}\text { A. mediterranei } \mathbf{S 6 9 9} \\
\Delta \text { rifA }\end{array}$ & $\rho^{\mathrm{a}}$ & $-c$ & [14] \\
\hline & Amexanthomycin B (7) & $\begin{array}{c}\text { A.mediterranei S699 } \\
\Delta \text { rifA }\end{array}$ & / & - & [14] \\
\hline & Amexanthomycin C (8) & $\begin{array}{c}\text { A. mediterranei } \mathrm{S699} \\
\Delta \text { rifA }\end{array}$ & / & - & [14] \\
\hline & Amexanthomycin D (9) & $\begin{array}{c}\text { A. mediterranei } \mathrm{S} 699 \\
\Delta \text { rifA }\end{array}$ & / & - & [14] \\
\hline
\end{tabular}


Table 1. Cont.

\begin{tabular}{|c|c|c|c|c|c|}
\hline Structure Types & Compounds & Sources & $\begin{array}{l}\text { CAS Registry } \\
\text { Numbers }\end{array}$ & $\begin{array}{l}\text { Habitats } \\
\left(\mathrm{T} / \mathrm{M}^{\mathrm{b}}\right)\end{array}$ & Refs. \\
\hline & Amexanthomycin E (10) & $\begin{array}{c}\text { A. mediterranei } \mathrm{S} 699 \\
\Delta \text { rifA }\end{array}$ & / & - & [14] \\
\hline & Amexanthomycin F (11) & $\begin{array}{c}\text { A. mediterranei } \mathrm{S} 699 \\
\Delta \text { rifA }\end{array}$ & / & - & [14] \\
\hline & Amexanthomycin G (12) & $\begin{array}{c}\text { A. mediterranei } \mathrm{S} 699 \\
\Delta \text { rifA }\end{array}$ & / & - & [14] \\
\hline & Amexanthomycin H (13/) & $\begin{array}{c}\text { A. mediterranei } \mathrm{S} 699 \\
\Delta \text { rifA }\end{array}$ & / & - & [14] \\
\hline & Amexanthomycin I (14) & $\begin{array}{c}\text { A. mediterranei } \mathrm{S} 699 \\
\Delta \text { rifA }\end{array}$ & / & - & [14] \\
\hline & Amexanthomycin J (15) & $\begin{array}{c}\text { A. mediterranei } \mathrm{S} 699 \\
\Delta \text { rifA }\end{array}$ & / & - & [14] \\
\hline & Mutactimycin E (16) & Amycolatopsis sp. 17128 & $1125635-23-5$ & Soil (T) & [15] \\
\hline & Mutactimycin A (17) & Amycolatopsis sp. 17128 & 131749-16-1 & Soil (T) & [15] \\
\hline & Mutactimycin D (18) & Amycolatopsis sp. 17128 & $138689-82-4$ & Soil (T) & [15] \\
\hline & $\begin{array}{c}\text { 1-Methoxy-3-methyl-8- } \\
\text { hydroxy-anthraquinone } \\
\text { (19) }\end{array}$ & A. thermoflava SFMA-103 & $67116-22-7$ & Soil (T) & {$[16,17]$} \\
\hline & $\begin{array}{c}\text { 7-O-Methyl-5-O- } \alpha-\mathrm{L}- \\
\text { rhamnopyranosylgenestein } \\
(20)\end{array}$ & $\begin{array}{c}\text { Amycolatopsis sp. YIM } \\
130642\end{array}$ & / & Squamarina sp. (T) & [18] \\
\hline & $\begin{array}{c}\text { 7-O- } \alpha-\mathrm{D}- \\
\text { Arabinofuranosyl } \\
\text { daidzein (21) }\end{array}$ & $\begin{array}{c}\text { Amycolatopsis sp. YIM } \\
130642\end{array}$ & 602329-64-6 & Squamarina sp. (T) & [18] \\
\hline & Prunetin (22) & $\begin{array}{c}\text { Amycolatopsis sp. YIM } \\
130642\end{array}$ & $552-59-0$ & Squamarina sp. (T) & [18] \\
\hline & Kakkatin (23) & $\begin{array}{c}\text { Amycolatopsis sp. YIM } \\
130642\end{array}$ & $57960-04-0$ & Squamarina sp. (T) & [18] \\
\hline & Isoformononetin (24) & $\begin{array}{l}\text { Amycolatopsis sp. YIM } \\
130642\end{array}$ & $486-63-5$ & Squamarina sp. (T) & [18] \\
\hline & Genistein (25) & $\begin{array}{l}\text { Amycolatopsis sp. YIM } \\
130642\end{array}$ & $446-72-0$ & Squamarina sp. (T) & [18] \\
\hline & Formononetin (26) & $\begin{array}{c}\text { Amycolatopsis sp. YIM } \\
130642\end{array}$ & $485-72-3$ & Squamarina sp. (T) & [18] \\
\hline & Sorbicillin (27) & $\begin{array}{c}\text { Amycolatopsis sp. YIM } \\
130687\end{array}$ & 79950-85-9 & P. borreri $(\mathrm{T})$ & [19] \\
\hline & Pradimicin-IRD (28) & $\begin{array}{l}\text { Amycolatopsis sp. } \\
\text { IRD-009 }\end{array}$ & $2226037-84-7$ & Soil (T) & [20] \\
\hline & $\begin{array}{c}(2 R, 3 R)-2-H y d r o x y-8-O- \\
\text { methyltetrangomycin } \\
(\mathbf{2 9})\end{array}$ & Amycolatopsis sp. Hca1 & 1391860-71-1 & O. chinensis $(\mathrm{T})$ & {$[21]$} \\
\hline & $\begin{array}{c}(2 R, 3 R)-2-H y d r o x y-5-O- \\
\text { methyltetrangomycin } \\
(30)\end{array}$ & Amycolatopsis sp. Hca1 & $1391860-72-2$ & O. chinensis $(\mathrm{T})$ & {$[21]$} \\
\hline & Amycomycin A (31) & Amycolatopsis sp. Hca1 & $1415935-15-7$ & O. chinensis $(\mathrm{T})$ & [22] \\
\hline & Amycomycin B (32) & Amycolatopsis sp. Hca1 & $1415935-16-8$ & O. chinensis $(\mathrm{T})$ & [22] \\
\hline & Tetrangomycin (33) & Amycolatopsis sp. Hca1 & $7351-08-8$ & O. chinensis $(\mathrm{T})$ & {$[21]$} \\
\hline
\end{tabular}


Table 1. Cont.

\begin{tabular}{|c|c|c|c|c|c|}
\hline Structure Types & Compounds & Sources & $\begin{array}{c}\text { CAS Registry } \\
\text { Numbers }\end{array}$ & $\begin{array}{l}\text { Habitats } \\
\left(\mathrm{T} / \mathrm{M}^{\mathrm{b}}\right)\end{array}$ & Refs. \\
\hline & $\operatorname{Pd} 116779(34)$ & Amycolatopsis sp. Hca1 & $102674-89-5$ & O. chinensis $(\mathrm{T})$ & [21] \\
\hline & Tetrangulol (35) & Amycolatopsis sp. Hca1 & $7414-92-8$ & O. chinensis $(\mathrm{T})$ & [21] \\
\hline & X-14881e (36) & Amycolatopsis sp. Hca1 & $85178-50-3$ & O. chinensis $(\mathrm{T})$ & [21] \\
\hline & Sakyomicin B (37) & Amycolatopsis sp. Hca1 & $86470-27-1$ & O. chinensis $(\mathrm{T})$ & [21] \\
\hline & Tetracyclinone (38) & Amycolatopsis sp. Hca1 & $86413-78-7$ & O. chinensis $(\mathrm{T})$ & [21] \\
\hline & Sakyomicin A (39) & Amycolatopsis sp. Hca1 & $86413-75-4$ & O. chinensis $(\mathrm{T})$ & [21] \\
\hline & Sakyomicin C (40) & Amycolatopsis sp. Hca1 & $86413-76-5$ & O. chinensis $(\mathrm{T})$ & [21] \\
\hline & Amycofuran (41) & A. saalfeldensis & / & Sponge (M) & [23] \\
\hline \multirow[t]{3}{*}{$\begin{array}{c}\text { Linear } \\
\text { polyketides }\end{array}$} & ECO-0501 (42) & A. orientalis ATCC 43,491 & $848087-04-7$ & - & [24] \\
\hline & $\begin{array}{l}\text { Modified analogs of } \\
\text { ECO-0501 (43-47) }\end{array}$ & A. orientalis ATCC 43,491 & $\begin{array}{l}848087-07-0, \\
848087-06-9 \\
848087-08-1 \\
848087-09-2, \\
921224-72-8\end{array}$ & - & [24] \\
\hline & Vancoresmycin (48) & $\begin{array}{c}\text { Amycolatopsis sp. ST } \\
101170\end{array}$ & $268728-82-1$ & - & [25] \\
\hline \multirow[t]{10}{*}{ Macrolides } & Amycolatopsin A (49) & $\begin{array}{l}\text { Amycolatopsis sp. } \\
\text { MST-108494 }\end{array}$ & 2209112-96-7 & Soil (T) & [26] \\
\hline & Amycolatopsin B (50) & $\begin{array}{l}\text { Amycolatopsis sp. } \\
\text { MST-108494 }\end{array}$ & $2209112-97-8$ & Soil (T) & [26] \\
\hline & Amycolatopsin C (51) & $\begin{array}{l}\text { Amycolatopsis sp. } \\
\text { MST-108494 }\end{array}$ & 2209112-98-9 & Soil (T) & [26] \\
\hline & $\begin{array}{c}\text { 2'-O-Succinyl-apoptolidin } \\
\text { A (52) }\end{array}$ & $\begin{array}{l}\text { Amycolatopsis sp. ICBB } \\
8242\end{array}$ & $1778681-11-0$ & Borneo (M) & [27] \\
\hline & $\begin{array}{c}\text { 3'-O-Succinyl-apoptolidin } \\
\text { A (53) }\end{array}$ & $\begin{array}{l}\text { Amycolatopsis sp. ICBB } \\
8242\end{array}$ & $1778681-12-1$ & Borneo (M) & [27] \\
\hline & Apoptolidin A (54) & $\begin{array}{l}\text { Amycolatopsis sp. ICBB } \\
8242\end{array}$ & 194874-06-1 & Borneo (M) & [27] \\
\hline & Apoptolidin B (55) & $\begin{array}{l}\text { Amycolatopsis sp. ICBB } \\
8242\end{array}$ & 861994-72-1 & Borneo (M) & [27] \\
\hline & Apoptolidin C (56) & $\begin{array}{l}\text { Amycolatopsis sp. ICBB } \\
8242\end{array}$ & 861994-73-2 & Borneo (M) & [27] \\
\hline & Apoptolidin D (57) & $\begin{array}{l}\text { Amycolatopsis sp. ICBB } \\
8242\end{array}$ & 929641-83-8 & Borneo (M) & [27] \\
\hline & Isoapoptolidin A (58) & $\begin{array}{l}\text { Amycolatopsis sp. ICBB } \\
8242\end{array}$ & $476647-30-0$ & Borneo (M) & [27] \\
\hline \multirow[t]{5}{*}{ Macrolactams } & Rifamycinoside A (59) & A. mediterranei $\mathrm{S} 699$ & $2329704-84-7$ & - & {$[28]$} \\
\hline & Rifamycinoside B (60) & A. mediterranei $\mathrm{S} 699$ & $2329704-85-8$ & - & [28] \\
\hline & $\begin{array}{l}\text { 28-Desmethyl-28- } \\
\text { hydroxyrifamycin W } \\
(\mathbf{6 1 )}\end{array}$ & A. mediterranei $\mathrm{S} 699$ & $2329704-86-9$ & - & [28] \\
\hline & $\begin{array}{c}\text { 27,28-Epoxy-28- } \\
\text { desmethylrifamycin W } \\
(\mathbf{6 2})\end{array}$ & A. mediterranei $\mathrm{S} 699$ & 2329704-87-0 & - & [28] \\
\hline & $\begin{array}{c}\text { 30-Hydroxyrifamycin } \mathrm{W} \\
\text { hemiacetal (63) }\end{array}$ & A. mediterranei $\mathrm{S} 699$ & 2329704-88-1 & - & [28] \\
\hline
\end{tabular}


Table 1. Cont.

\begin{tabular}{|c|c|c|c|c|c|}
\hline Structure Types & Compounds & Sources & $\begin{array}{c}\text { CAS Registry } \\
\text { Numbers }\end{array}$ & $\begin{array}{l}\text { Habitats } \\
\left(\mathrm{T} / \mathrm{M}^{\mathrm{b}}\right)\end{array}$ & Refs. \\
\hline & $\begin{array}{c}\text { 20-Hydroxyrifamycin S } \\
(\mathbf{6 4 )}\end{array}$ & A. mediterranei 6699 & / & - & [28] \\
\hline & Rifamycin S (65) & A. mediterranei $\mathrm{S} 699$ & $13553-79-2$ & - & [28] \\
\hline & $\begin{array}{c}\text { 16,17-Dehydrorifamycin G } \\
\text { (66) }\end{array}$ & A. mediterranei $\mathrm{S} 699$ & $75922-16-6$ & - & [28] \\
\hline & Rifamycin O (67) & A. mediterranei $\mathrm{S} 699$ & $14487-05-9$ & - & [28] \\
\hline & Rifamycin Z (68) & A. mediterranei $\mathrm{S} 699$ & 79486-49-0 & - & [28] \\
\hline & Rifamycin W (69) & A. mediterranei $\mathrm{S} 699$ & $53904-81-7$ & - & [28] \\
\hline & Rifamorpholine A (70) & Amycolatopsis sp. HCa4 & $2101982-41-4$ & L. migratoria $(\mathrm{T})$ & [29] \\
\hline & Rifamorpholine B (71) & Amycolatopsis sp. HCa4 & $2101982-45-8$ & L. migratoria $(\mathrm{T})$ & [29] \\
\hline & Rifamorpholine C (72) & Amycolatopsis sp. HCa4 & $2101982-52-7$ & L. migratoria $(\mathrm{T})$ & [29] \\
\hline & Rifamorpholine D (73) & Amycolatopsis sp. HCa4 & $2101982-58-3$ & L. migratoria $(\mathrm{T})$ & [29] \\
\hline & Rifamorpholine E (74) & Amycolatopsis sp. HCa4 & 2101982-62-9 & L. migratoria $(\mathrm{T})$ & [29] \\
\hline & Macrotermycin A (75) & Amycolatopsis sp. M39 & $1311284-73-7$ & M. natalensis $(\mathrm{T})$ & [30] \\
\hline & Macrotermycin B (76) & Amycolatopsis sp. M39 & 2095035-09-7 & M. natalensis $(\mathrm{T})$ & [30] \\
\hline & Macrotermycin C (77) & Amycolatopsis sp. M39 & $2095035-10-0$ & M. natalensis $(\mathrm{T})$ & {$[30]$} \\
\hline & Macrotermycin D (78) & Amycolatopsis sp. M39 & 2095035-11-1 & M. natalensis $(\mathrm{T})$ & [30] \\
\hline & Ansamycin (79) & A. alba DSM 44262 & $2256052-40-9$ & - & [31] \\
\hline \multirow[t]{18}{*}{$\begin{array}{l}\text { Thiazolyl } \\
\text { peptides }\end{array}$} & Nocathiacin I (80) & A. fastidiosa & $214044-52-7$ & - & [32-34] \\
\hline & Nocathiacin II (81) & A. fastidiosa & $256230-46-3$ & - & {$[32,33]$} \\
\hline & Nocathiacin III (82) & A. fastidiosa & $256230-47-4$ & - & {$[32,33]$} \\
\hline & Nocathiacin IV (83) & A. fastidiosa & $400650-12-6$ & - & {$[32,33]$} \\
\hline & Thiazomycin (84) & A. fastidiosa & 905946-70-5 & - & [32-34] \\
\hline & Thiazomycin A (85) & A. fastidiosa & $905978-04-3$ & - & [33] \\
\hline & Mj347-81f4 b (86) & A. fastidiosa & 214044-53-8 & - & [35] \\
\hline & Thiazomycin B (87) & A. fastidiosa & $905946-73-8$ & - & [35] \\
\hline & Thiazomycin C (88) & A. fastidiosa & $851664-21-6$ & - & [35] \\
\hline & Thiazomycin D (89) & A. fastidiosa & $905946-71-6$ & - & [35] \\
\hline & Thiazomycin $\mathrm{E}_{1}$ (90) & A. fastidiosa & 905946-72-7 & - & {$[35]$} \\
\hline & Thiazomycin $\mathrm{E}_{2}$ (91) & A. fastidiosa & 905946-75-0 & - & [35] \\
\hline & Thiazomycin $\mathrm{E}_{3}(\mathbf{9 2})$ & A. fastidiosa & 905946-76-1 & - & [35] \\
\hline & Thioamycolamide A (93) & Amycolatopsis sp. $26-4$ & / & Iriomote Island $(\mathrm{T})$ & [36] \\
\hline & Thioamycolamide B (94) & Amycolatopsis sp. $26-4$ & / & Iriomote Island $(\mathrm{T})$ & [36] \\
\hline & Thioamycolamide C (95) & Amycolatopsis sp. $26-4$ & / & Iriomote Island $(\mathrm{T})$ & [36] \\
\hline & Thioamycolamide D (96) & Amycolatopsis sp. $26-4$ & / & Iriomote Island $(\mathrm{T})$ & {$[36]$} \\
\hline & Thioamycolamide E (97) & Amycolatopsis sp. 26-4 & / & Iriomote Island $(\mathrm{T})$ & {$[36]$} \\
\hline \multirow[t]{3}{*}{ Cyclic peptides } & PRG-A (98) & $\begin{array}{c}\text { Amycolatopsis sp. } \\
\text { ML1-hF4 }\end{array}$ & $421547-03-7$ & Soil (T) & [37] \\
\hline & PRG-B (99) & $\begin{array}{c}\text { Amycolatopsis sp. } \\
\text { ML1-hF4 }\end{array}$ & 2112795-88-5 & Soil (T) & [38] \\
\hline & PRG-C (100) & $\begin{array}{l}\text { Amycolatopsis sp. } \\
\text { ML1-hF4 }\end{array}$ & 2112795-89-6 & Soil (T) & [38] \\
\hline
\end{tabular}


Table 1. Cont.

\begin{tabular}{|c|c|c|c|c|c|}
\hline Structure Types & Compounds & Sources & $\begin{array}{l}\text { CAS Registry } \\
\text { Numbers }\end{array}$ & $\begin{array}{l}\text { Habitats } \\
\left(\mathrm{T} / \mathrm{M}^{\mathrm{b}}\right)\end{array}$ & Refs. \\
\hline & PRG-D (101) & $\begin{array}{l}\text { Amycolatopsis sp. } \\
\text { ML1-hF4 }\end{array}$ & $2112795-90-9$ & Soil (T) & [38] \\
\hline & Valgamicin A (102) & $\begin{array}{l}\text { Amycolatopsis sp. } \\
\text { ML1-hF4 }\end{array}$ & 2271221-78-2 & Soil (T) & [39] \\
\hline & Valgamicin C (103) & $\begin{array}{l}\text { Amycolatopsis sp. } \\
\text { ML1-hF4 }\end{array}$ & $2271221-79-3$ & Soil (T) & [39] \\
\hline & Valgamicin T (104) & $\begin{array}{l}\text { Amycolatopsis sp. } \\
\text { ML1-hF4 }\end{array}$ & $2271221-80-6$ & Soil (T) & [39] \\
\hline & Valgamicin V (105) & $\begin{array}{l}\text { Amycolatopsis sp. } \\
\text { ML1-hF4 }\end{array}$ & $2271221-81-7$ & Soil (T) & [39] \\
\hline \multirow[t]{13}{*}{ Glycopeptides } & Chloroorienticin A (106) & A. orientalis PA- 45052 & $118395-73-6$ & - & [40] \\
\hline & Chloroorienticin B (107) & A. orientalis PA-45052 & $118373-81-2$ & - & [40] \\
\hline & Chloroorienticin C (108) & A. orientalis PA-45052 & $118373-82-3$ & - & {$[40]$} \\
\hline & Chloroorienticin D (109) & A. orientalis PA- 45052 & 118373-83-4 & - & [40] \\
\hline & Chloroorienticin E (110) & A. orientalis PA- 45052 & $118373-84-5$ & - & [40] \\
\hline & Orienticin A (111) & A. orientalis PA-45052 & 111073-20-2 & - & [40] \\
\hline & Orienticin D (112) & A. orientalis PA- 45052 & $112848-46-1$ & - & [40] \\
\hline & Vancomycin (113) & A. orientalis PA-45052 & $1404-90-6$ & - & [40] \\
\hline & $\begin{array}{c}\text { Vancomycin aglycone } \\
\text { (114) }\end{array}$ & A. orientalis PA- 45052 & $82198-76-3$ & - & [40] \\
\hline & MM 47,761 (115) & A. orientalis NCBI 12608 & $126985-51-1$ & - & [41] \\
\hline & MM 49,721 (116) & A. orientalis NCBI 12608 & $126985-52-2$ & - & [41] \\
\hline & Eremomycin B (117) & $\begin{array}{l}\text { A. orientalis subsp. } \\
\text { Eremomycini }\end{array}$ & $1193347-07-7$ & - & [42] \\
\hline & Eremomycin (118) & $\begin{array}{l}\text { A. orientalis subsp. } \\
\text { Eremomycini }\end{array}$ & $110865-90-2$ & - & [42] \\
\hline \multirow[t]{10}{*}{$\begin{array}{c}\text { Amide } \\
\text { derivatives }\end{array}$} & Albachelin (119) & A. alba & 2055362-14-4 & - & [43] \\
\hline & Albisporachelin (120) & A. albispora $\mathrm{WP}^{\mathrm{T}}$ & / & Sediment (M) & [44] \\
\hline & A-102395 (121) & $\begin{array}{c}\text { Amycolatopsis sp. SANK } \\
60206\end{array}$ & $1003904-77-5$ & Soil (T) & [45] \\
\hline & $\begin{array}{c}\text { Amycocyclopiazonic acid } \\
\text { (122) }\end{array}$ & A. saalfeldensis & / & Sponge (M) & [23] \\
\hline & Amycolactam (123) & A. saalfeldensis & / & Sponge (M) & [23] \\
\hline & $\begin{array}{c}\text { Carbamothioic S-acid } \\
\text { (124) }\end{array}$ & A. alba DSM $44262 \triangle a b m 9$ & / & - & [46] \\
\hline & $\begin{array}{c}\text { Amycophthalazinone A } \\
\text { (125) }\end{array}$ & $\begin{array}{l}\text { Amycolatopsis sp. YIM } \\
130642\end{array}$ & / & Squamarina sp. (T) & [18] \\
\hline & $\begin{array}{c}2- \\
\text { Pyruvoylaminobenzamide } \\
(\mathbf{1 2 6})\end{array}$ & $\begin{array}{c}\text { Amycolatopsis sp. YIM } \\
130687\end{array}$ & $18326-62-0$ & P. borreri $(\mathrm{T})$ & [19] \\
\hline & (-)-Chrysogine (127) & $\begin{array}{c}\text { Amycolatopsis sp. YIM } \\
130687\end{array}$ & $42599-89-3$ & P. borreri $(\mathrm{T})$ & [19] \\
\hline & $\begin{array}{l}\text { 4-(3-Methylbut-2-enyloxy) } \\
\text { benzamide (128) }\end{array}$ & $\begin{array}{c}\text { Amycolatopsis sp. YIM } \\
130687\end{array}$ & 116208-80-1 & P. borreri $(\mathrm{T})$ & [19] \\
\hline
\end{tabular}


Table 1. Cont.

\begin{tabular}{|c|c|c|c|c|c|}
\hline Structure Types & Compounds & Sources & $\begin{array}{l}\text { CAS Registry } \\
\text { Numbers }\end{array}$ & $\begin{array}{l}\text { Habitats } \\
\left(T / M^{b}\right)\end{array}$ & Refs \\
\hline & Acetotryptamide (129) & $\begin{array}{c}\text { Amycolatopsis sp. YIM } \\
130687\end{array}$ & $1016-47-3$ & P. borreri $(\mathrm{T})$ & [19] \\
\hline & 2-Acetamidophenol (130) & $\begin{array}{c}\text { Amycolatopsis sp. YIM } \\
130687\end{array}$ & $614-80-2$ & P. borreri $(\mathrm{T})$ & [19] \\
\hline & Anthranilic acid (131) & $\begin{array}{c}\text { Amycolatopsis sp. YIM } \\
130687\end{array}$ & $118-92-3$ & P. borreri $(\mathrm{T})$ & [19] \\
\hline & Phenacetamide (132) & $\begin{array}{c}\text { Amycolatopsis sp. YIM } \\
130687\end{array}$ & $103-81-1$ & P. borreri $(\mathrm{T})$ & [19] \\
\hline & $\begin{array}{c}\text { 2-Carbamoyl-3-hydroxy- } \\
\text { 1,4-naphthoquinone } \\
(\mathbf{1 3 3})\end{array}$ & $\begin{array}{c}\text { Amycolatopsis sp. YIM } \\
130687\end{array}$ & $103646-20-4$ & P. borreri $(\mathrm{T})$ & [19] \\
\hline & Echinosporin (134) & $\begin{array}{c}\text { Amycolatopsis sp. YIM } \\
\text { PH20520 }\end{array}$ & $79127-35-8$ & Soil (T) & [47] \\
\hline & $\begin{array}{c}\text { 7-Deoxyechinosporin } \\
\text { (135) }\end{array}$ & $\begin{array}{c}\text { Amycolatopsis sp. YIM } \\
\text { PH20520 }\end{array}$ & $431945-10-7$ & Soil (T) & [47] \\
\hline & Dipyrimicin A (136) & $\begin{array}{c}\text { Amycolatopsis sp. } \\
\text { K16-0194 }\end{array}$ & $1235020-43-5$ & - & [48] \\
\hline & Dipyrimicin B (137) & $\begin{array}{c}\text { Amycolatopsis sp. } \\
\text { K16-0194 }\end{array}$ & $1332747-97-3$ & - & [48] \\
\hline & $\begin{array}{l}\text { 1-(10-Aminodecyl) } \\
\text { pyridinium (138) }\end{array}$ & A. alba var. nov. DVR D4 & $1421439-67-9$ & Sediment (M) & [49] \\
\hline & Siderochelin A (139) & Amycolatopsis sp. LZ149 & $77550-87-9$ & $\begin{array}{l}\text { Cynodon dactylon } \\
(\mathrm{T})\end{array}$ & [50] \\
\hline & Siderochelin B (140) & Amycolatopsis sp. LZ149 & $2252179-56-7$ & $\begin{array}{l}\text { Cynodon dactylon } \\
(\mathrm{T})\end{array}$ & [50] \\
\hline & Siderochelin C (141) & Amycolatopsis sp. LZ149 & $2252179-55-6$ & $\begin{array}{c}\text { Cynodon dactylon } \\
(\mathrm{T})\end{array}$ & [50] \\
\hline & Siderochelin D (142) & Amycolatopsis sp. LZ149 & $2249835-41-2$ & $\begin{array}{l}\text { Cynodon dactylon } \\
\text { (T) }\end{array}$ & [50] \\
\hline & Epoxyquinomicin A (143) & A. sulphurea MK299-95F4 & 175448-31-4 & Soil (T) & [51] \\
\hline & Epoxyquinomicin B (144) & A. sulphurea MK299-95F4 & $175448-32-5$ & Soil (T) & [51] \\
\hline & Epoxyquinomicin C (145) & A. sulphurea MK299-95F4 & 200496-85-1 & Soil (T) & [51] \\
\hline & Epoxyquinomicin D (146) & A. sulphurea MK299-95F4 & 200496-86-2 & Soil (T) & [51] \\
\hline \multirow[t]{9}{*}{$\begin{array}{c}\text { Glycoside } \\
\text { derivatives }\end{array}$} & Tigloside (147) & $\begin{array}{c}\text { Amycolatopsis sp. NN0 } \\
21702\end{array}$ & $216590-44-2$ & - & [52] \\
\hline & $\begin{array}{l}\text { 2,2'-Di-O- } \beta \text {-D- } \\
\text { glucopyranosyl- } \alpha \text {-D- } \\
\text { glucopyranosyl } \alpha \text {-D- } \\
\text { glucopyranoside }(\mathbf{1 4 8})\end{array}$ & $\begin{array}{c}\text { Amycolatopsis sp. NN0 } \\
21702\end{array}$ & / & - & [52] \\
\hline & Actinotetraose I (149) & Amycolatopsis sp. HCa1 & $1427319-31-0$ & O. chinensis $(\mathrm{T})$ & [53] \\
\hline & Actinotetraose J (150) & Amycolatopsis sp. HCa1 & $1427319-40-1$ & O. chinensis $(\mathrm{T})$ & [53] \\
\hline & Actinotetraose K (151) & Amycolatopsis sp. HCa1 & $1427319-41-2$ & O. chinensis $(\mathrm{T})$ & [53] \\
\hline & Actinotetraose A (152) & Amycolatopsis sp. HCa1 & $1421368-85-5$ & O. chinensis $(\mathrm{T})$ & [53] \\
\hline & Actinotetraose B (153) & Amycolatopsis sp. HCa1 & $1421368-86-6$ & O. chinensis $(\mathrm{T})$ & [53] \\
\hline & Actinotetraose C (154) & Amycolatopsis sp. HCa1 & $1421368-87-7$ & O. chinensis $(\mathrm{T})$ & [53] \\
\hline & Actinotetraose L (155) & Amycolatopsis sp. HCa1 & $216590-44-2$ & O. chinensis $(\mathrm{T})$ & [54] \\
\hline
\end{tabular}


Table 1. Cont.

\begin{tabular}{|c|c|c|c|c|c|}
\hline Structure Types & Compounds & Sources & $\begin{array}{l}\text { CAS Registry } \\
\text { Numbers }\end{array}$ & $\begin{array}{l}\text { Habitats } \\
\left(\mathrm{T} / \mathrm{M}^{\mathrm{b}}\right)\end{array}$ & Refs. \\
\hline \multirow[t]{2}{*}{$\begin{array}{l}\text { Enediyne } \\
\text { derivatives }\end{array}$} & Amycolamycin A (156) & Amycolatopsis sp. HCa4 & $2243041-65-6$ & L. migratoria $(\mathrm{T})$ & [55] \\
\hline & Amycolamycin B (157) & Amycolatopsis sp. HCa4 & $2243041-66-7$ & L. migratoria $(\mathrm{T})$ & [55] \\
\hline \multirow[t]{2}{*}{ Sesquiterpenes } & $\begin{array}{c}(E)-3-\text { methyl-5-(2,6,6- } \\
\text { trimthyl-3-oxocyclohex-1- } \\
\text { enyl) pent-2-enoic acid } \\
(\mathbf{1 5 8})\end{array}$ & A. alba DSM 44262 & $2247139-21-3$ & - & {$[31]$} \\
\hline & $\begin{array}{l}(E)-3-m e t h y l-5-(2,6,6- \\
\text { trimthyl-4-oxocyclohex-2- } \\
\text { enyl) pent-2-en-oic acid } \\
(\mathbf{1 5 9 )}\end{array}$ & A. alba DSM 44262 & $2256051-20-2$ & - & [31] \\
\hline
\end{tabular}

${ }^{a}$ The CAS registry number was not found; ${ }^{b}$ T: terrestrial environment; M: marine environment; ${ }^{c}$ The habitat was not mentioned.

\subsection{Polyphenols}

Polyphenolic compounds are a large family of natural products and some of them show a series of excellent function in health [56], such as anti-allergenic, anti-inflammatory, anti-microbial, antioxidant, antithrombotic, cardio protective, and vasodilatory effects [57]. The investigation on secondary metabolites of Amycolatopsis sp. ML630-mF1 from the soil sample collected in Toba of Japan led to the isolation of five new compounds named kigamicins A-E (1-5). These compounds showed potent effects to resist methicillin-resistant Staphylococcus aureus (MRSA) with the $\mathrm{IC}_{50}$ values ranging in $0.03-0.22 \mu \mathrm{M}$. Besides, they inhibited PANC-1 cell survival under a nutrient-starved condition. Typically, kigamicin D was found to suppress diverse mouse cancer cell line growth, and the $\mathrm{IC}_{50}$ value was about $0.95 \mu \mathrm{M}$ [13]. In the absence of nutrition, kigamicin D exhibited preferential cytotoxicity to cancer cells and could inhibit the PI3K/Akt pathway [58]. A total of 10 novel pentangular polyphenols defined as amexanthomycins A-J (6-15) were obtained from the fermentation products of Amycolatopsis mediterranei S699 $\Delta$ rifA (the A. mediterranei S699 mutant strain). These compounds were produced through deleting polyketide synthase genes related to rifamycin biosynthesis. In this study, the effects of the above compounds on suppressing topoisomerases II $\alpha$ (Topo II $\alpha$ ) were examined. The results showed that compounds 6-8 exhibited moderate inhibitory activity against Topo II $\alpha(500 \mu \mathrm{M})$, while compounds 9-15 showed no activities [14].

Anthraquinones are the most abundant among the various natural quinone compounds. Earlier, they were mainly used as dyes. But later, their antibacterial, anti-inflammatory, and antiviral effects were discovered. A new anthracycline, namely, mutactimycin E (16) with two known compounds mutactimycin A (17) and D (18) were isolated from the EtOAc extract of Amycolatopsis sp. 17,128 collected from the soil sample near Ruby, Arizona. It had moderate effects to resist some Gram-positive bacteria [15]. Investigation of secondary metabolites from Amycolatopsis thermoflava SFMA-103 led to the isolation of the 1-methoxy-3-methyl-8hydroxy-anthraquinone (19) pigment from the rhizosphere soil of sunflower collected in Medak, Andhra Pradesh, South India. Compound 19 displayed infusive anti-cancer activity in-vitro to resist lymphoblastic leukemia as well as lung cancer cells, with the $\mathrm{IC}_{50}$ values of 16.98 and $10.3 \mu \mathrm{M}$, separately. In addition, the DPPH assay showed that this compound had favorable capacity to scavenge free radicals with the $\mathrm{EC}_{50}$ value of $18.2 \mu \mathrm{g} / \mathrm{mL}$ [16]. Furthermore, compound 19 suppressed $\alpha$-glucosidase and $\alpha$-amylase with $\mathrm{IC}_{50}$ values of 10.32 and $0.91 \mu \mathrm{M}$, respectively. According to the research on the oral dose for Wistar rats, compound 19 remarkably suppressed the elevated glucose level at a dose of $100 \mathrm{mg} / \mathrm{kg}$. Its toxicity was further assayed by the genotoxic analysis in both Chinese Hamster Ovary cells (in-vitro) and Swiss albino mice (in-vivo). The studies indicated that compound 19 had little effect on mouse survival. It was concluded that compound 19 was used at $100 \mathrm{mg} / \mathrm{kg}$ 
to treat hyperglycemia via inhibiting $\alpha$-glucosidase and $\alpha$-amylase enzymes without inducing any genotoxic effect [17]. 7-O-Methyl-5-O- $\alpha$-L-rhamnopyranosylgenestein (20) was a novel isoflavonoid glycoside, while 7-O- $\alpha$-D-arabinofuranosyl daidzein (21) was firstly extracted from natural sources. These two compounds, along with 5 known isoflavonoids, prunetin (22), kakkatin (23), isoformononetin (24), genistein (25), and formononetin (26) were produced by the lichen-associated Amycolatopsis sp. YIM 130642. Compounds 20 and 21 showed modest bacteriostatic activities against one or more pathogenic strains of Candida albicans, Escherichia coli, MRSA, S. aureus, and Salmonella typhi with their minimal inhibition concentrations (MICs) in the range of 32-256 $\mu \mathrm{g} / \mathrm{mL}$ [18]. Sorbicillin (27) was isolated from the lichen-derived actinomycete strain Amycolatopsis sp. YIM 130,687 [19]. Isolation and identification of a new polycyclic antibiotic, pradimicin-IRD (28), was reported from the rare actinobacteria Amycolatopsis sp. IRD-009, which was collected from soil sample of Brazilian rainforest undergoing restoration area. Compound 28 exhibited antimicrobial activity against Streptococcus agalactiae-97, S. aureus-211 and Pseudomonas aeruginosa ATCC 27.859 with MIC values of $3.15 \mu \mathrm{g} / \mathrm{mL}$. In addition, the cytotoxicity of compound 28 was determined by MTT assay, which inhibited HCT-116 colon carcinoma, MM 200 melanoma, MCF-7 breast carcinoma and RPE non-tumor retinal pigment epithelial cells with $\mathrm{IC}_{50}$ values of $0.8,2.7,1.55$ and $1.48 \mu \mathrm{M}$, respectively [20]. Compound 28 could induce DNA damage (increased $\gamma \mathrm{H} 2 \mathrm{AX}$ and p21), cell cycle arrest (reduced Rb phosphorylation) and apoptosis (PARP1 and caspase 3 cleavage). It was capable of impacting on double stranded DNA which might be the novel target for compound 28 [59]. Three new angucyclines, $(2 R, 3 R)$-2-hydroxy-8-O-methyltetrangomycin (29), (2R,3R)-2-hydroxy-5-Omethyltetrangomycin (30), amycomycin B (31), and a novel angucyclinone derivative, amycomycin A (32), with eight known compounds, tetrangomycin (33), pd116779 (34), tetrangulol (35), X-14881E (36), sakyomicin B (37), tetracyclinone (38), sakyomicin A (39), and sakyomicin C (40), were produced by Amycolatopsis sp. Hca1 [21,22], which was collected from the gut of Oxya chinensis. Compounds 33, 34, 39 and 40 possessed cytotoxic activities against the HeLa cells with the $\mathrm{IC}_{50}$ values of $0.27,0.11,0.56$ and $0.39 \mu \mathrm{M}$, respectively, and compound $\mathbf{4 0}$ was also cytotoxic against BGC823, HepG2, A375, KB, and Ghost-R5 $\times 4$ cell lines with the $\mathrm{IC}_{50}$ values of $11.03,17.36,17.5$ and $14.0 \mu \mathrm{M}$, respectively. Amycofuran (41) is a new benzofuran glycoside isolated from Amycolatopsis saalfeldensis collected from a sponge sample [23]. All 41 polyphenols described above are presented in Figure 1. 

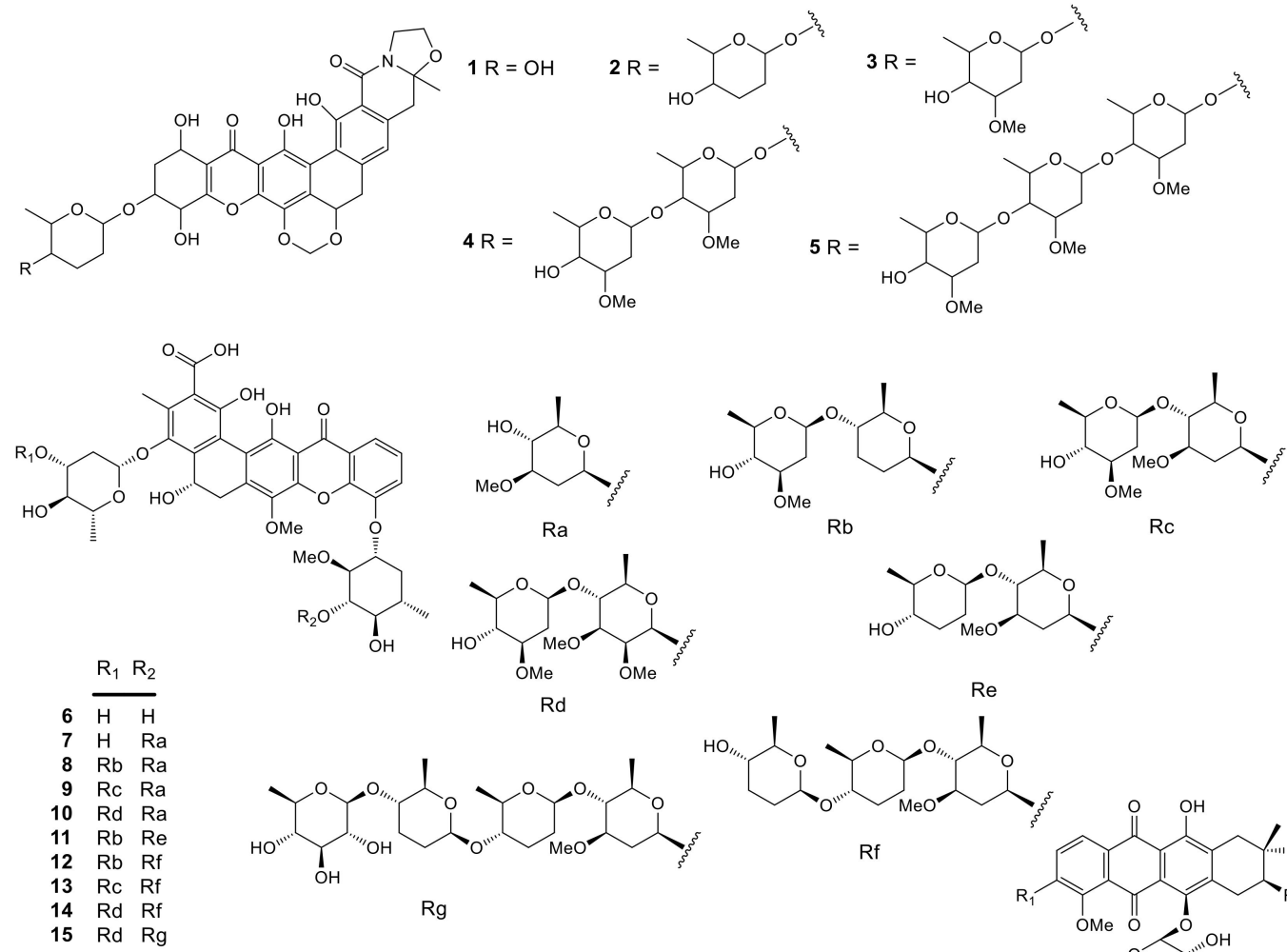<smiles>COc1cc(C)cc2c1C(=O)c1c(O)cccc1C2=O</smiles>

19<smiles>COc1cc(O[C@@H]2OC(C)[C@@H](O)C(O)C2O)c2c(=O)c(-c3ccc(O)cc3)coc2c1</smiles>
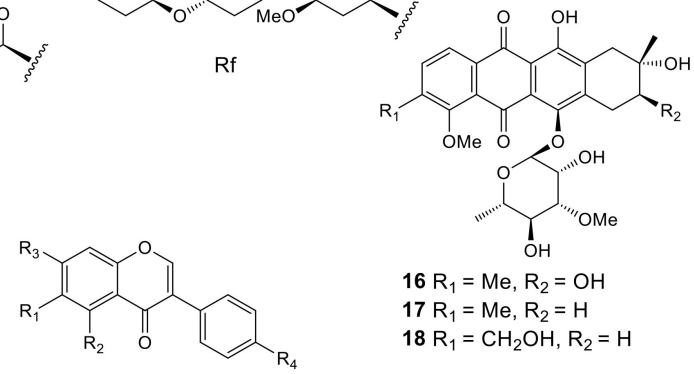

$16 \mathrm{R}_{1}=\mathrm{Me}, \mathrm{R}_{2}=\mathrm{OH}$

$17 \mathrm{R}_{1}=\mathrm{Me}, \mathrm{R}_{2}=\mathrm{H}$

$18 \mathrm{R}_{1}=\mathrm{CH}_{2} \mathrm{OH}, \mathrm{R}_{2}=\mathrm{H}$

$22 \mathrm{R}_{1}=\mathrm{H}, \mathrm{R}_{2}=\mathrm{OH}, \mathrm{R}_{3}=\mathrm{OMe}, \mathrm{R}_{4}=\mathrm{OH}$ $23 \mathrm{R}_{1}=\mathrm{OH}, \mathrm{R}_{2}=\mathrm{H}, \mathrm{R}_{3}=\mathrm{OMe}, \mathrm{R}_{4}=\mathrm{OH}$ $24 \mathrm{R}_{1}=\mathrm{H}, \mathrm{R}_{2}=\mathrm{H}, \mathrm{R}_{3}=\mathrm{OMe}, \mathrm{R}_{4}=\mathrm{OH}$ $25 \mathrm{R}_{1}=\mathrm{H}, \mathrm{R}_{2}=\mathrm{R}_{3}=\mathrm{R}_{4}=\mathrm{OH}$

$26 \mathrm{R}_{1}=\mathrm{R}_{2}=\mathrm{H}, \mathrm{R}_{3}=\mathrm{OH}, \mathrm{R}_{4}=\mathrm{OMe}$

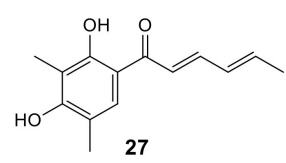<smiles>COC(=O)c1c(C)cc2c(c1O)-c1c(cc3c(c1O)C(=O)c1cc(OC)c(C)c(O)c1C3=O)[C@@H](OC1C[C@](C)(N)[C@@H](O)C(C)O1)[C@H]2OC</smiles>

28

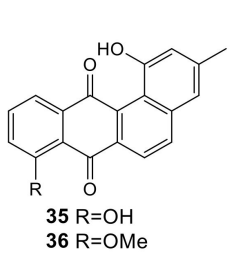<smiles>[R]c1cccc2c1C(=O)c1cc([R])c3c(c1C2=O)C[C@](C)(O)[C@@H]([R3])C3=O</smiles>

$29 \mathrm{R}_{1}=\mathrm{OMe}, \mathrm{R}_{2}=\mathrm{H}, \mathrm{R}_{3}=\mathrm{OH}$ $30 \mathrm{R}_{1}=\mathrm{OH}, \mathrm{R}_{2}=\mathrm{OMe}, \mathrm{R}_{3}=\mathrm{OH}$ $33 \mathrm{R}_{1}=\mathrm{OH}, \mathrm{R}_{2}=\mathrm{H}, \mathrm{R}_{3}=\mathrm{H}$ $34 \mathrm{R}_{1}=\mathrm{OH}, \mathrm{R}_{2}=\mathrm{H}, \mathrm{R}_{3}=\mathrm{OH}$

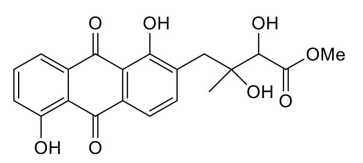

31

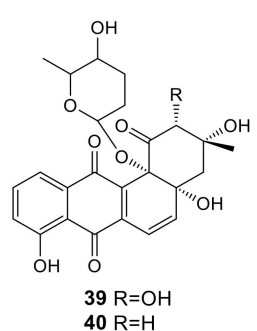

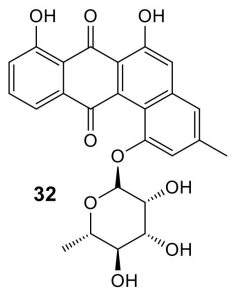

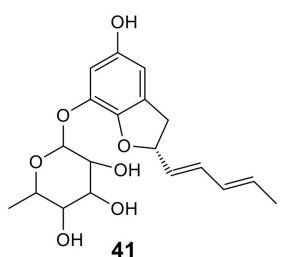

Figure 1. Structures of polyphenols (1-41) from Amycolatopsis.

\subsection{Linear Polyketides}

Through genomic analysis, the strain Amycolatopsis orientalis ATCC 43,491 was found to be the producer of vancomycin, which possessed genetic loci to produce over $10 \mathrm{sec}-$ ondary metabolites apart from vancomycin. It was estimated that a gene cluster containing the type I polyketide synthase mediated the biosynthesis for a new glycosidic polyketide ECO-0501 (42) [24]. Compound 42 exhibited stronger antibacterial activity than van- 
comycin against S. aureus ATCC TM 6538P in pH 5.0 and 6.0 with the MIC values of 0.125 and $0.25 \mu \mathrm{g} / \mathrm{mL}$. This compound had potent effect on resisting Gram-positive bacteria MRSA and vancomycin-resistant Enterococci (VRE) strains. The mechanistic studies proved that ECO-0501 may impact on either cell wall or membrane biosynthesis [60]. In addition, compound 42 chemical modified analogs, including esterified 43-45, N-acetylated 46 , and hydrogenated 47 were reported. Compound 46 showed antibacterial activity against S. aureus ATCC TM 6538P with MIC values of $0.25,0.5$ and $2 \mu \mathrm{g} / \mathrm{mL}$ in $\mathrm{pH} 5,6$ and 7 , respectively. The novel antibiotic vancoresmycin (48) was obtained from the culture broth of Amycolatopsis sp. ST 101170. It showed a potent effect on resisting the Gram-positive strains of E. faecium, S. aureus, S. pneumonia, S. epidermidis, S. pyogenes, together with a variety of drug-resistant microorganisms. The $\mathrm{IC}_{50}$ values were found to be less than $0.05 \mu \mathrm{M}$. By a non-pore forming and concentration-dependent depolarization mechanism, compound 48 selectively targeted the cytoplasmic membrane of gram-positive bacteria [61]. No inhibitory effect against gram-negative bacteria or anti-fungal activity was observed [25]. All 7 linear polyketides described above are presented in Figure 2.

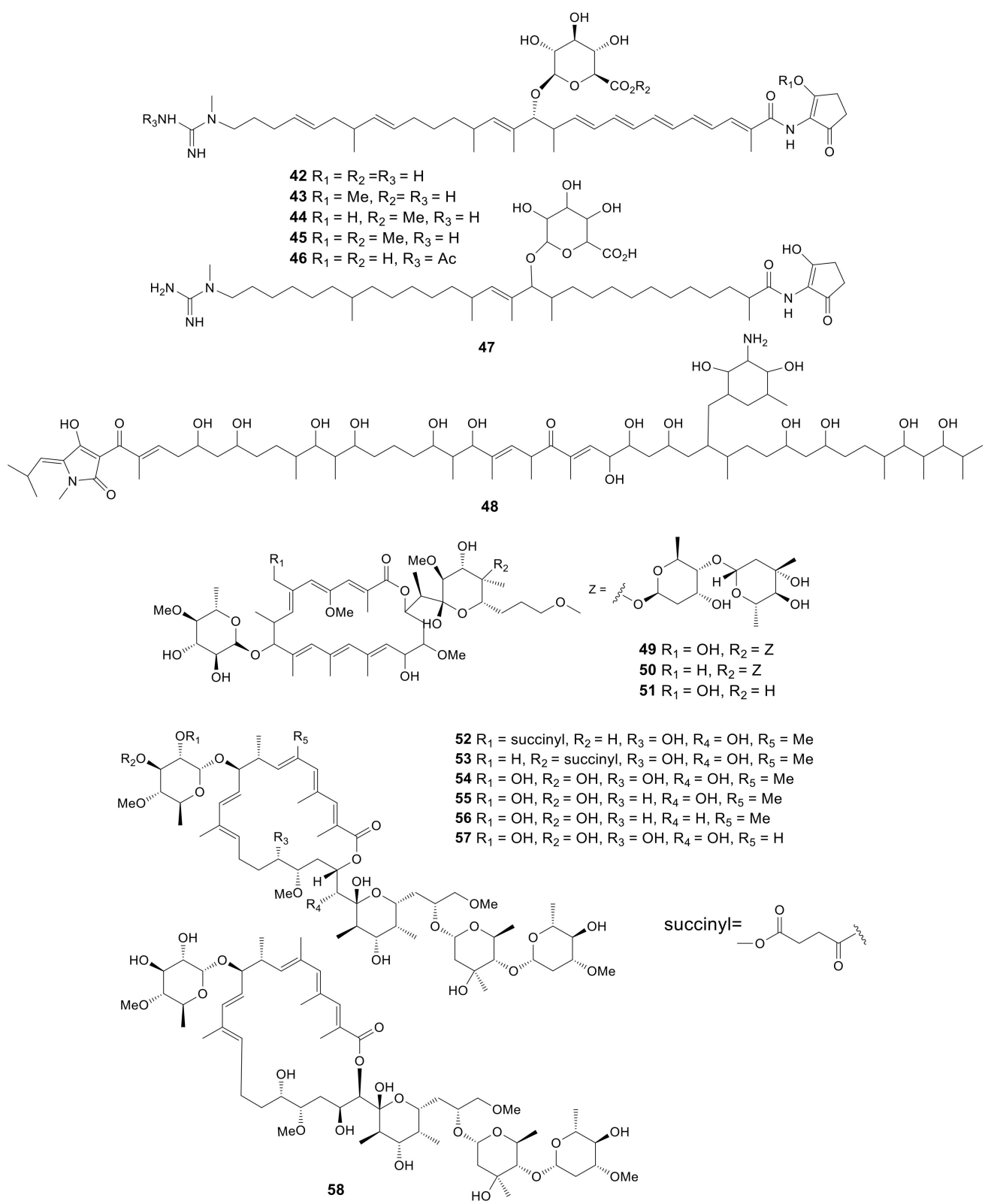

Figure 2. Structures of linear polyketides (42-48) and macrolides (49-58) from Amycolatopsis. 


\subsection{Macrolides}

Three novel glycosylated macrolactones, amycolatopsins A-C (49-51), were produced by Amycolatopsis sp. MST-108494 obtained from the soil in southern Australia. Both compounds 49 and 51 prevented $M$. tuberculosis $\left(\mathrm{H} 37 \mathrm{Rv}, \mathrm{IC}_{50}\right.$ values of 4.4 and $\left.5.7 \mu \mathrm{M}\right)$ and M. bovis (BCG; $\mathrm{IC}_{50}$ values of 0.4 and $2.7 \mu \mathrm{M}$ ) from growing within the liquid culture. In addition, compounds $\mathbf{4 9}$ and $\mathbf{5 0}$ showed significant toxicity to the human lung cancer (NCIH-460; $\mathrm{IC}_{50}$ values of 1.2 and $0.28 \mu \mathrm{M}$ ) and colon carcinoma (SW620; $\mathrm{IC}_{50}$ values of 0.08 and $0.14 \mu \mathrm{M}$ ) cell lines. Whereas, compound 51 showed 5- to 100-fold less cytotoxicity with $\mathrm{IC}_{50}$ values of 5.9 and $10 \mu \mathrm{M}$, respectively [26]. Two new apoptolidins, $2^{\prime}-O$-succinylapoptolidin A (52) and 3'-O-succinyl-apoptolidin A (53), with five known compounds, apoptolidins A-D (54-57) and isoapoptolidin A (58), were produced by the Indonesian Amycolatopsis sp. ICBB 8242 isolated from the Black Water Ecosystems in Kalimantan. Compound 54 could inhibit the human $\mathrm{H} 292$ and HeLa cells with $\mathrm{IC}_{50}$ values of 0.02 and $0.04 \mu \mathrm{M}$, respectively. Compounds 52 and 53 could suppress the human H292 cell with $\mathrm{IC}_{50}$ values of 0.09 and $0.08 \mu \mathrm{M}$, respectively [27]. All 10 macrolides described above are presented in Figure 2.

\subsection{Macrolactams}

Macrolactams have been used in clinical trials since 1940 [62], in which penicillin and cephalosporins are the representative antibiotics. For better exploiting the rifamycin diversity, the Amycolatopsis mediterranei S699 strain was cultured on the YMG agar media. Eleven rifamycin congeners, including six new compounds, rifamycinosides A (59) and B (60), 28-desmethyl-28-hydroxyrifamycin W (61), 27,28-epoxy-28-desmethylrifamycin W (62), 30-hydroxyrifamycin $W$ hemiacetal (63) and 20-hydroxyrifamycin $S$ (64), with five known compounds, rifamycin S (65), 16,17-dehydrorifamycin G (66), rifamycins $\mathrm{O}(67)$, $\mathrm{Z}(68)$ and $\mathrm{W}(69)$, were isolated. Compounds 59 and 60 possess the similar skeleton of rifamycin glycosides. The polyketide cores of these two compounds presented the new rifamycin ansa chain cleavage pattern. Compound $\mathbf{6 4}$ showed potent inhibitory activity against T3SS, caused G2/M phase arrest, and attracted DNA damage in HCT116 cells [28]. Five unusual macrolactams, rifamorpholines A-E (70-74), were isolated from Amycolatopsis sp. HCa4 collected from the gut of Locusta migratoria. Compounds 71 and 73 possessed antimicrobial activity against MRSA, S. aureus, S. pyogenes, Bacillus subtilis, and Micrococcus luteus with MIC values in the range of 0.5-8.0 Mm [29]. Four new 20-membered glycosylated polyketide macrolactams, macrotermycins A-D (75-78), were produced by Amycolatopsis sp. M39 collected from a Macrotermes natalensis. Compound 75 exhibited antimicrobial activity against B. subtilis ATCC 6051, S. aureus ATCC 25923, Saccharomyces cerevisiae ATCC 9763 and C. albicans ATCC 24,433 with MIC values of 1.0, 1.5, 5.0, 10, respectively. And compound 77 exhibited antimicrobial activity against $B$. subtilis ATCC 6051, S. aureus ATCC 25923, Saccharomyces cerevisiae ATCC 9763 and C. albicans ATCC 24,433 with MIC values of 15, 10, 20, $25 \mu \mathrm{g} / \mathrm{mL}$, respectively [30]. A novel compound, ansamycin (79), was produced by Amycolatopsis alba DSM 44262. However, this compound exhibited no antimicrobial activity for S. aureus, B. subtilis, P. aeruginosa and C. albicans [31]. All 21 macrolactams described above are presented in Figure 3. 


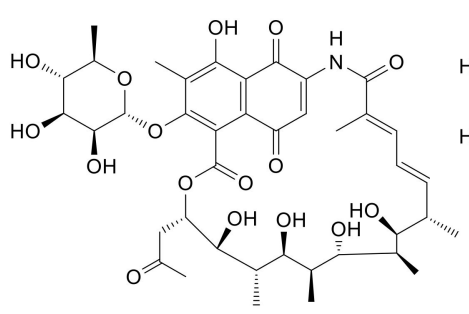

59

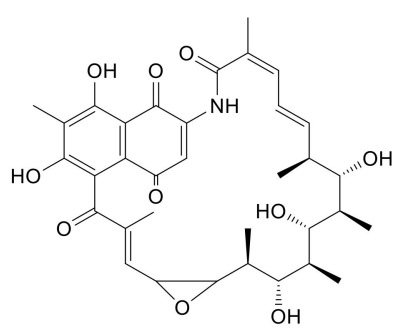

62

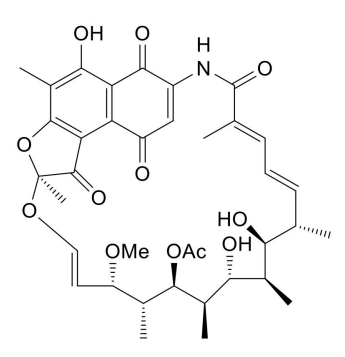

65

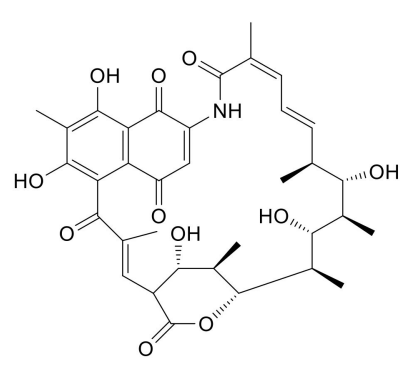

68

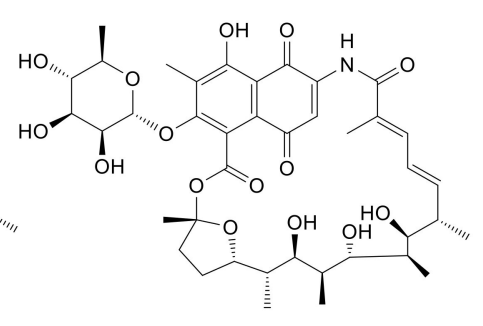

60

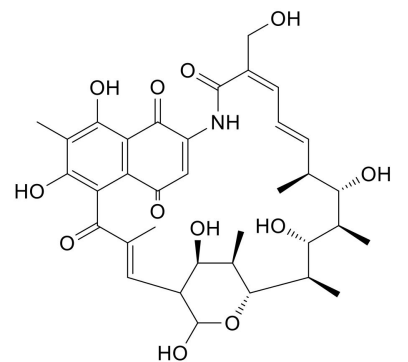

63

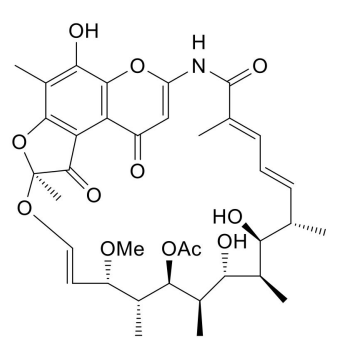

66

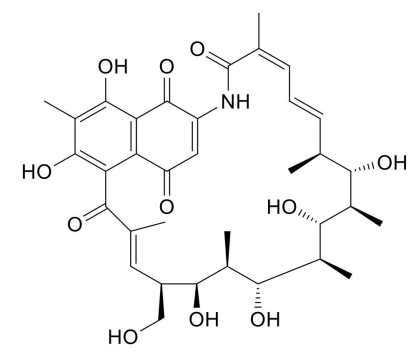

69

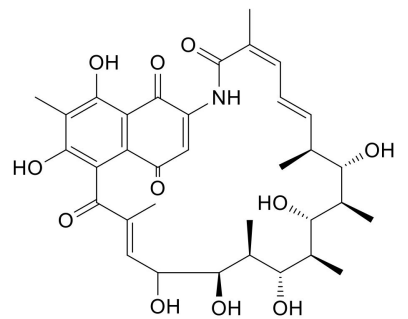

61

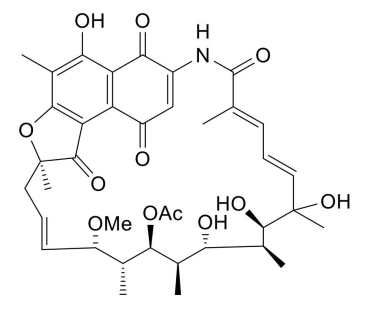

64

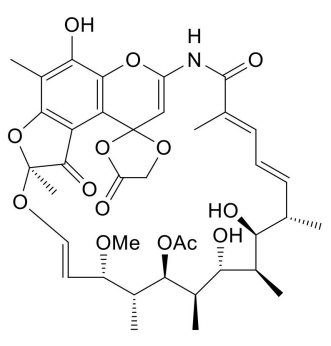

67

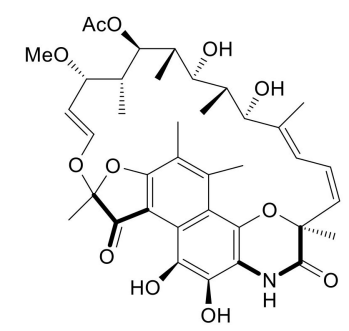

70

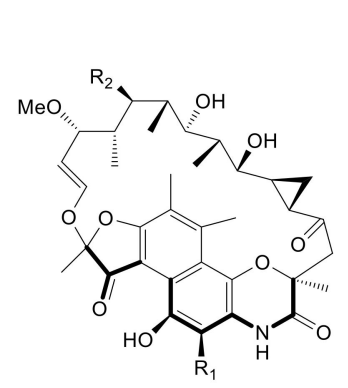

$71 \mathrm{R}_{1}=\mathrm{H}, \mathrm{R}_{2}=\mathrm{OH}$

$72 \mathrm{R}_{1}=\mathrm{H}, \mathrm{R}_{2}=\mathrm{OAc}$

$73 \mathrm{R}_{1}=\mathrm{OH}, \mathrm{R}_{2}=\mathrm{OH}$

$74 \mathrm{R}_{1}=\mathrm{OH}, \mathrm{R}_{2}=\mathrm{OAC}$

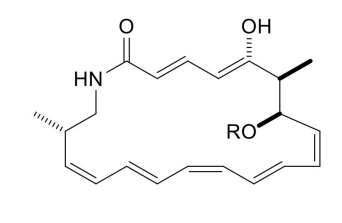

75

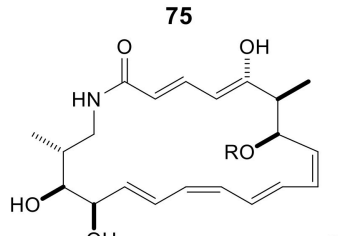

77

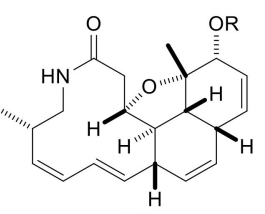

76

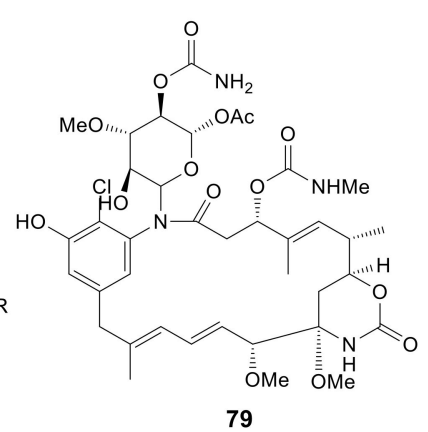

78

Figure 3. Structures of macrolactams (59-79) from Amycolatopsis. 


\subsection{Thiazolyl Peptides}

After chromatographically fractionating the fermentation broth extract of Amycolatopsis fastidiosa, 4 known nocathiacins I-IV (80-83) along with 2 novel thiazolyl peptides, thiazomycin (84) and thiazomycin A (85) were isolated [32-34]. Compounds 84 and 85 showed potent inhibition against Gram-positive bacteria. Continued chemical screening led to the separation of an intermediate product and six new thiazolyl peptide congeners, MJ347-81F4 B (86), thiazomycins B-D (87-89), and $\mathrm{E}_{1}-\mathrm{E}_{3}$ (90-92). The new compounds were tested for their antimicrobial activity against gram-positive bacterial strains of S. aureus, E. faecalis, S. pneumonia, and other drug-resistant strains. The results indicated that compounds 87-89 effectively inhibited the growth of the pathogenic bacteria described above, whereas compounds 90-92 showed no obvious antimicrobial activity [35]. Five novel compounds thioamycolamides A-E (93-97) were obtained from the fermentation products of Amycolatopsis sp. 26-4 isolated from Iriomote Island near Okinawa, Japan. They were cycliclipopeptides containing sulfur, thioether rings, thiazoline, along with fatty acid moieties. Compounds 93 and 96 showed moderate cytotoxicity with the $\mathrm{IC}_{50}$ values ranging from 6.53 to $21.22 \mu \mathrm{M}$. However, compound 97 had an $\mathrm{IC}_{50}$ value greater than $100 \mu \mathrm{M}$ [36]. All 18 thiazolyl peptides described above are presented in Figure 4.
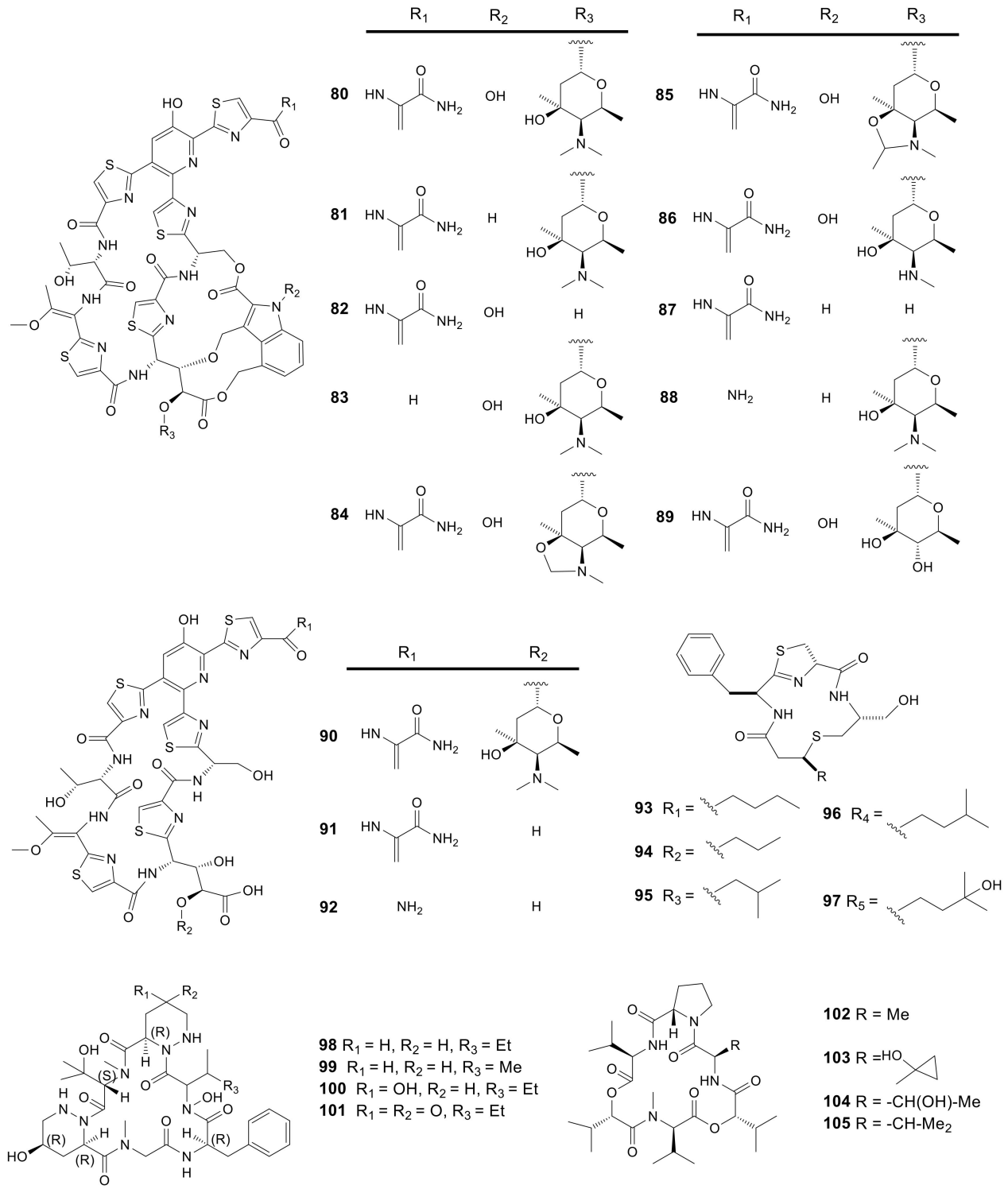

$102 \mathrm{R}=\mathrm{Me}$

$103 \mathrm{R}=\mathrm{H}$

$104 \mathrm{R}=-\mathrm{CH}(\mathrm{OH})-\mathrm{Me}$

$105 \mathrm{R}=-\mathrm{CH}-\mathrm{Me}_{2}$

Figure 4. Structures of thiazolyl peptides (80-97) and cyclic peptides (98-105) from Amycolatopsis. 


\subsection{Cyclic Peptides}

Cyclic peptides always possess antibacterial, antitumor, hypotoxic, immunosuppressive activities and have a merit of favorable binding affinity and selectivity for certain receptors [63]. The limited conformational freedom conferred by cyclization enables cyclic peptides to span large surfaces while retaining the conformational restriction that yields high selectivity and affinity. Such advantages render them the ideal selection for developing therapeutics [64]. While screening antibiotics against MRSA and VRE, the novel cyclic peptide, PRG-A (98) containing the distinct piperazic acid, was obtained from the fermentation broth of Amycolatopsis sp. ML1-hF4 isolated from a soil sample collected at Shinagawa, Tokyo, Japan [37]. During the optimization of the production process of PRG-A, three new derivatives, namely, PRG-B (99), C (100), and D (101), were further isolated from the same strain. This study examined the effects of these new PRGs on resisting a variety of Grampositive and -negative bacteria, like VRE and MRSA. The results showed that compounds 98 and 100 exhibited potent and broad antibacterial activity against gram-positive bacteria with the $\mathrm{IC}_{50}$ value of about $0.72 \mu \mathrm{M}$. The antibacterial activity of compounds 99 and 101 was lower, with the $\mathrm{IC}_{50}$ values ranging from 5.61 to $23.37 \mu \mathrm{M}$. However, all compounds failed to show anti-bacterial activity against gram-negative bacteria [38]. Compound 98 disrupted cell membrane function by disruption of membrane potential [65]. Another four new cyclic depsipeptide compounds, named valgamicins $A(\mathbf{1 0 2}), C$ (103), $T$ (104) and V (105), were isolated from Amycolatopsis sp. ML1-hF4. Compound 105 possessed an excellent cytotoxicity against a series of human tumor cell lines, such as MIA Paca 2 (Pancreatic cancer), HGC-27 (Gastric cancer), GSS (Gastric cancer), 5637 (Bladder cancer), NCI-H1650 (Lung cancer), GI-1 (Glioma), NB16 (Neuroblastoma), ME-180 (Cervical cancer), and HSC-490 (Tongue cancer), with $\mathrm{IC}_{50}$ values from 6.6 to $21.6 \mu \mathrm{M}$ [39]. All 8 cyclic peptides described above are presented in Figure 4.

\subsection{Glycopeptides}

Glycopeptide antibiotics are used as a key weapon in against bacteria, especially multidrugresistant Gram-positive pathogens. The ground-breaking work about glycopeptide antibiotics resistance mechanisms in Gram-positive pathogens were published in the 1990s [66]. Chloroorienticins were similar to vancomycin-type antibiotics. Five new chloroorienticins A-E (106-110), orienticins A (111) and D (112), vancomycin (113) and its aglycone (114) were isolated from the fermentation broth of Amycolatopsis orientalis PA-45052. Some of them showed higher antibacterial activity than vancomycin. Compounds 106-110 showed significant antibacterial activity against $S$. aureus JC-1 and MRSA with MIC values in the range of $0.2-0.78 \mu \mathrm{g} / \mathrm{mL}$. Vancomycin (113) was comparatively against these two bacteria with MIC values of 0.78 and $1.58 \mu \mathrm{g} / \mathrm{mL}$, respectively [40]. MM 47,761 (115) and MM 49,721 (116) were obtained from Amycolatopsis orientalis NCBI 12,608 and displayed a favorable antimicrobial effect on Gram-positive strains. Compounds 115 and 116 could inhibit B. subtilis ATCC6633, Corynebacterium xerosis NCTC9755, M. luteus NCTC8340, S. aureus Oxford, S. aureus Russell, S. aureus V573 MRa, S. saprophyticus FL1, S. epidermidis 60137, S. epidermidis 54815, Streptococcus pyogenes CN10, S. agalactiae Hester, S. sanguis ATCC 10556, S. faecalis I with the MIC values from 0.5 to $8 \mu \mathrm{g} / \mathrm{mL}$ [41]. A new bioactive antibiotic, eremomycin B (117), along with one known antibiotic, eremomycin (118), were isolated from the culture broth of Amycolatopsis orientalis subsp. Eremomycini [42]. All 13 glycopeptides described above are presented in Figure 5. 


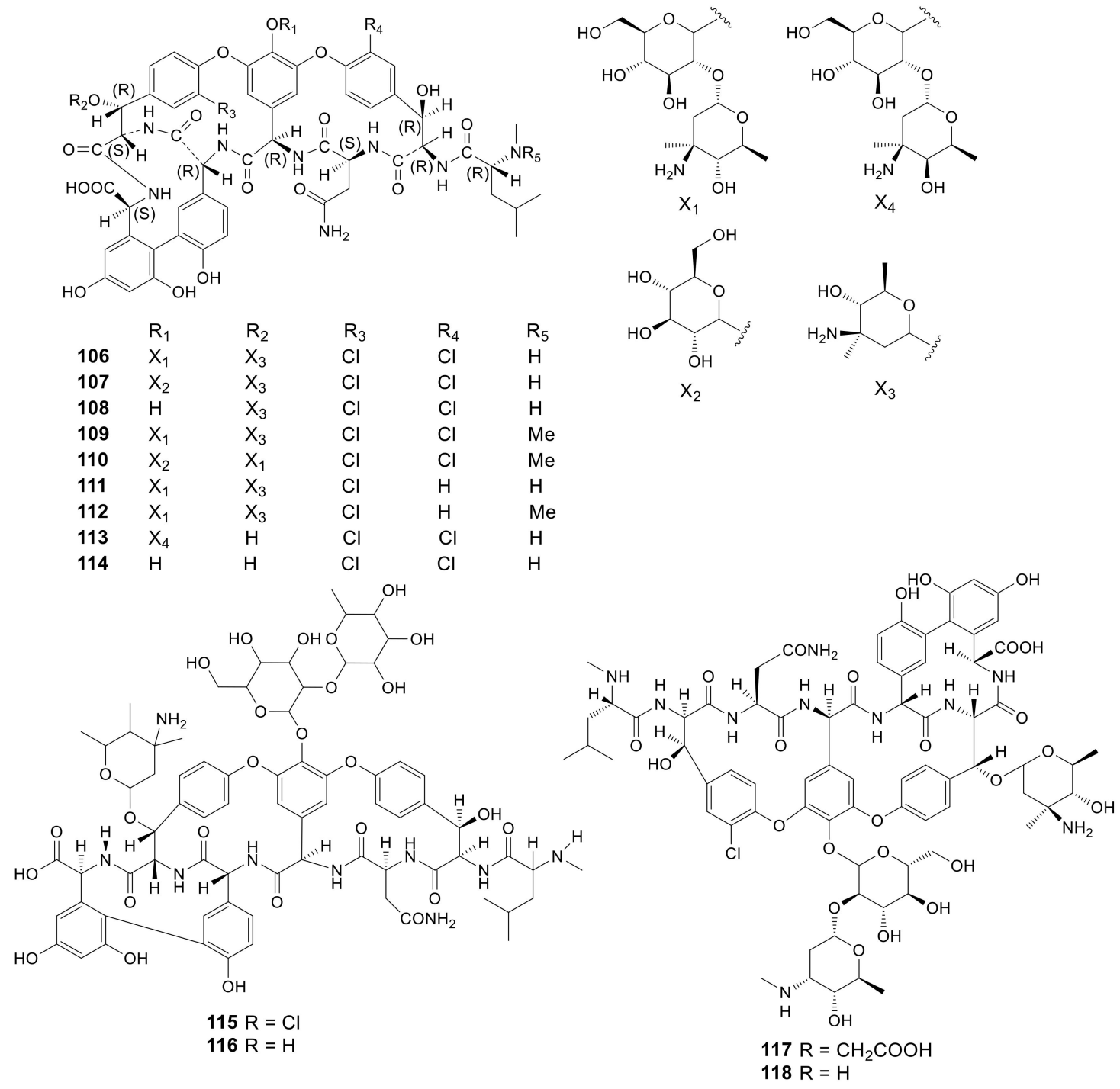

Figure 5. Structures of glycopeptides (106-118) from Amycolatopsis.

\subsection{Amide Derivatives}

Albachelin (119), a novel siderophore, was obtained from the Amycolatopsis alba culture with iron depletion. Then, ESI-MS/MS together with NMR spectroscopy was performed to characterize the gallium (III) complex [43]. Albisporachelin (120), a new siderophore, was obtained from the Amycolatopsis albispora $\mathrm{WP}^{\mathrm{T}}$ culture broth with iron depletion using sediments obtained at $-2945 \mathrm{~m}$ from the Indian Ocean [44]. In the course of bacterial translocase I inhibitor screening, a new compound, A-102395 (121) was isolated from Amycolatopsis sp. SANK 60206. A-102395 (isolated from a soil sample collected in Hokkaido, Japan) showed strong inhibition on the bacterial translocase I with the $\mathrm{IC}_{50}$ value of $0.01 \mu \mathrm{M}$. This compound showed no antibacterial effect on the analyzed strains [45]. The indole alkaloids are associated with cyclopiazonic acids, which were previously only detected in fungi. In addition, amycocyclopiazonic acid (122), along with amycolactam (123), was obtained from Amycolatopsis saalfeldensis. Combined with spectroscopic data, the structures of compounds $\mathbf{1 2 2}$ and $\mathbf{1 2 3}$ were identified to be new indole alkaloids related to cyclopiazonic acids. Amycolactam was significantly cytotoxic to gastric cancer SNU638 and colon cancer HCT116 cells, and the $\mathrm{IC}_{50}$ values were 0.8 and $2.0 \mu \mathrm{M}$, respectively [23]. The novel derivative of carbamothioic S-acid (124) was obtained from Amycolatopsis alba DSM 44262 $\Delta \mathrm{abm} 9$ fermentation extract exposed to $25 \mathrm{mM} \mathrm{N}$-acetyl-Dglucosamine [46]. Amycophthalazinone A (125), the first example of natural occurring new 
phthalazinone derivative, was discovered from the fermentation products of the lichenassociated Amycolatopsis sp. YIM 130,642 [18]. Compound 125 had potent antibacterial effect on S. typhi, C. albicans, and S. aureus, with $\mathrm{IC}_{50}$ values of $6.92,13.84$, and $6.92 \mu \mathrm{M}$, respectively. 2-Pyruvoylaminobenzamide (126), (-)-chrysogine (127), 4-(3-methylbut-2enyloxy) benzamide (128), acetotryptamide (129), 2-acetamidophenol (130), anthranilic acid (131), phenacetamide (132) and 2-carbamoyl-3-hydroxy-1,4-naphthoquinone (133) were isolated from the cultural of Amycolatopsis sp. YIM 130687. Compounds 128 and 133 were firstly discovered from microorganisms [19].

Two novel echinosporin derivatives, echinosporin (134) and 7-deoxyechinosporin (135), were obtained from the culture broth of Amycolatopsis sp. YIM PH20520 from the Panax notoginseng rhizosphere soil samples collected from Wenshang, Yunnan Province of China. Compound 134 had potent effect on resisting four P. notoginseng root-rot pathogens, including Fusarium solani, Fusarium oxysporum, Phoma herbarum and Alternaria panax, and the MIC values were 64, 64, 64 and $32 \mu \mathrm{g} / \mathrm{mL}$, respectively. Compound 135 had moderate effect on resisting F. solani, F. oxysporum, P. herbarum and A. panax, with the MIC values of $128,128,128$ and $64 \mu \mathrm{g} / \mathrm{mL}$, respectively [47]. Two novel compounds, dipyrimicins A (136) and B (137), were produced by Amycolatopsis sp. K16-0194. Compound 136 exhibited excellent antimicrobial activity against S. cerevisiae ATCC 9763, Kocuria rhizophila ATCC 9341, B. subtilis ATCC 6633, E. coli NIHJ, Xanthomonas campestris pv. oryzae KB 88 with the inhibition zone from 16 to $21 \mathrm{~mm}$ in a dose of $30 \mu \mathrm{g}$ and from 11 to $27 \mathrm{~mm}$ in a dose of $100 \mu \mathrm{g}$. Compound 136 also displayed strong cytotoxic activity against Hela 3S, HT29, A549, H1299, Panc1, THP-1, Jarkat and HL-60 with the $\mathrm{IC}_{50}$ values of $5.1 \pm 0.5,6.2 \pm 0.3,4.3 \pm 0.2$, $9.2 \pm 0.5,9.4 \pm 3.5,9.4 \pm 3.5,4.4 \pm 0.5$ and $3.9 \pm 0.7 \mu \mathrm{M}$, respectively. Compound 137 only had a moderate inhibition on $\mathrm{H} 1299$ cell line with an $\mathrm{IC}_{50}$ value of $6.8 \pm 3.3 \mu \mathrm{M}$ [48]. A new pyridinium, 1-(10-aminodecyl) pyridinium (138), was produced by Amycolatopsis alba var. nov. DVR D4, which was collected from marine sediment of Visakhapatnam coast. With a dose of $1000 \mu \mathrm{g} / \mathrm{mL}$, compound 138 had a great effect on HeLa, MCF-7 (breast cancer), U87MG (brain cancer) cells with percentage viability (\%) and percentage inhibition (\%) of 39.54,60.36, 58.15 and $60.46,39.64,41.85$, respectively [49]. Three novel siderochelins D-F (140-142), with the known siderochelin A (139) were obtained from Amycolatopsis sp. LZ149, derived from the rhizosphere of Cynodon dactyIon in the Baicheng beach of Xiamen, Fujian, China. Compound 139 exhibited antimicrobial activity against Bacillus pumilus CMCC55051, B. subtilis CMCC63501, E. coli CMCC4103 and S. aureus CMCC2600 with the diameter of inhibition zone from 10 to $15 \mathrm{~mm}$ [50]. Epoxyquinomicins A-D (143-146), four new compounds were isolated from the cluture broth of A. sulphurea MK299-95F4 from the soil sample collected at Sendai City, Miyagi Prefecture, Japan. Compounds 143 and 144 exhibited antimicrobial activity against $M$. luteus IFO3333 and M. luteus PCI1001 with MIC values from 3.12 to $6.25 \mu \mathrm{g} / \mathrm{mL}$ [51]. Compounds 143-146 (1-4 mg/kg) possessed an inhibition ability of type II collagen-induced arthritis [67]. All 28 amide and amino derivatives described above are presented in Figure 6. 

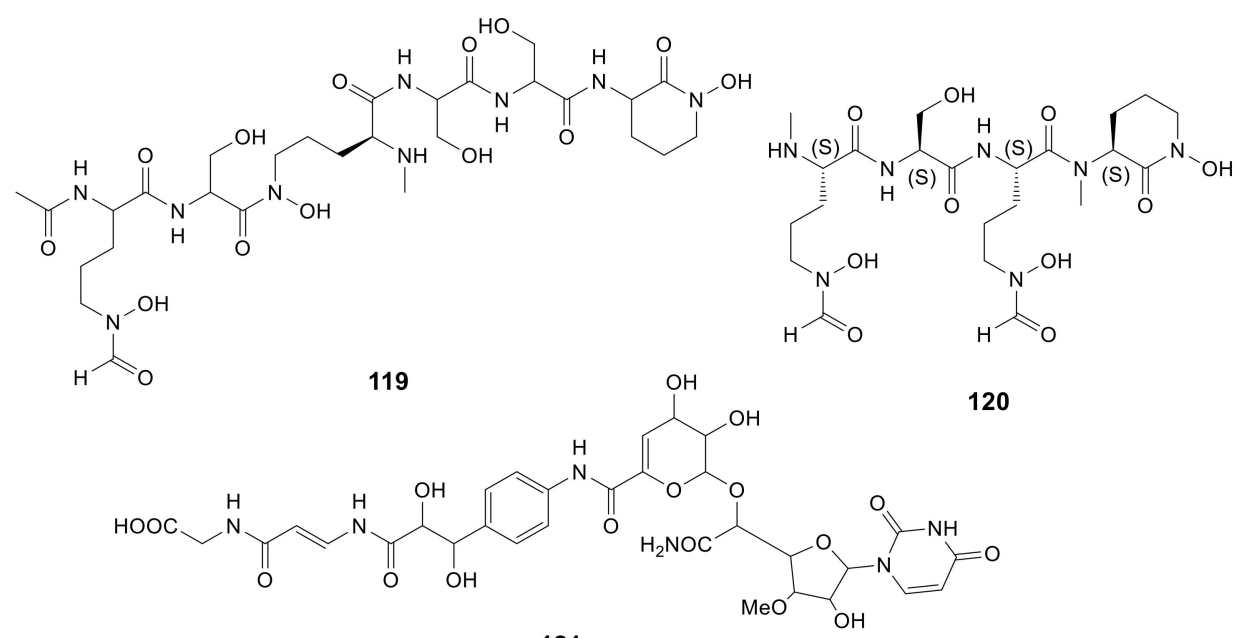

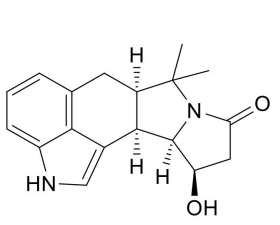

122

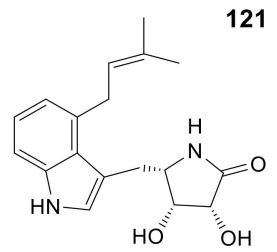

123

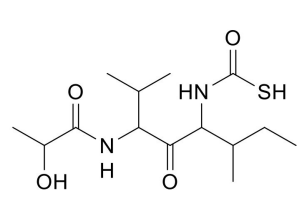

124<smiles>O=C1NNC2(CCCCC2)c2ccccc21</smiles>

125<smiles>CC(=O)C(=O)Nc1ccccc1C(N)=O</smiles>

126<smiles>CC(O)c1nc2ccccc2c(=O)[nH]1</smiles>

127<smiles>NC(=O)Cc1ccccc1</smiles>

132<smiles>CCOc1cc(C(N)=O)nc(-c2ccccn2)c1O</smiles>

137<smiles>COc1cccnc1C1=N[C@H](C(=O)O)C[C@]1(C)O</smiles>

141<smiles>CC(C)=CCOc1ccc(C(N)=O)cc1</smiles><smiles>CC(=O)NCCc1c[nH]c2ccccc12</smiles>

129<smiles>CC(=O)Nc1ccccc1O</smiles>

130<smiles>Nc1ccccc1C(=O)O</smiles>

131<smiles>NC(=O)C1=C(O)C(=O)c2ccccc2C1=O</smiles>

134<smiles>NC(=O)C1=CC2CC3OC2C3O1</smiles>

135<smiles>C[C@]1(O)C[C@@H](C(N)=O)N=C1c1ncccc1O</smiles><smiles>Cc1cc(C(N)=O)[nH]c1-c1ncccc1O</smiles>

142
139<smiles>[R]c1cccc(C(=O)NC2=CC(=O)[C@@]3(CO)O[C@H]3C2=O)c1O</smiles>

$144 \mathrm{R}=\mathrm{H}$<smiles>CCOc1cc(C(=O)O)nc(-c2ccccn2)c1O</smiles>

136<smiles>C[C@]1(O)C[C@@H](C(=O)O)N=C1c1ncccc1O</smiles><smiles>[R]c1cccc(C(=O)NC2=CC(=O)[C@@]3(CO)O[C@H]3C2=O)c1O</smiles>

Figure 6. Structures of amide derivatives (119-146) from Amycolatopsis.

\subsection{Glycoside Derivatives}

HPLC-diode array screening was used to isolate tigloside (147) and 2,2'-di-O- $\beta$-Dglucopyranosyl- $\alpha$-D-glucopyranosyl $\alpha$-D-glucopyranoside (148) from the Amycolatopsis sp. NN0 21,702 mycelium. Chromatographic approaches were used to purify these new com- 
pounds, while NMR spectroscopy together with chemical degradation assays was adopted to confirm their structures [52]. Three new tetrasaccharide derivatives, actinotetraoses I-K (149-151), with three known compounds, actinotetraoses A-C (152-154), were isolated from Amycolatopsis sp. HCa1, which was collected from the gut of grasshopper [53]. Another novel tetrasaccharide derivative, actinotetraose L (155), was also obtained from the Amycolatopsis sp. HCa1 [54]. However, these compounds showed no significant bioactivity. The 9 glycoside derivatives described above are presented in Figure 7.

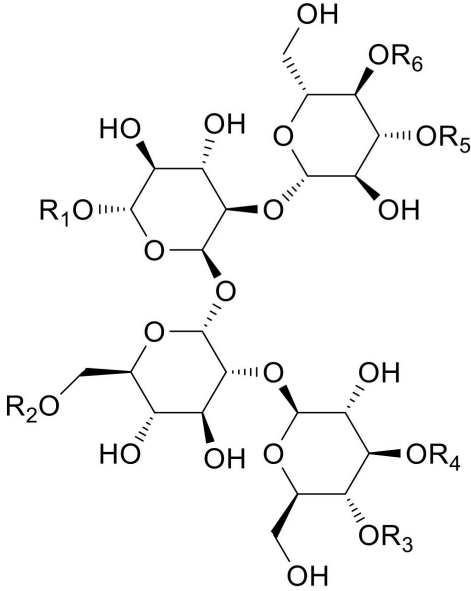

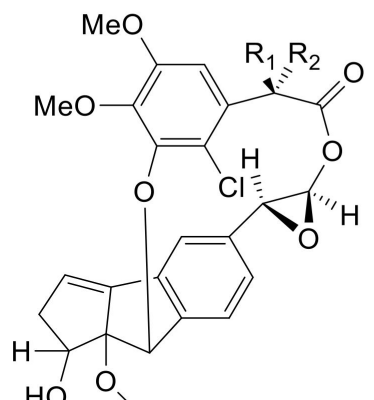

$156 \mathrm{R}_{1}=\mathrm{OH}, \mathrm{R}_{2}=\mathrm{H}$ $157 \mathrm{R}_{1}=\mathrm{H}, \mathrm{R}_{2}=\mathrm{OH}$<smiles>CC1=C(CC/C(C)=C/C(=O)O)C(C)(C)CCC1=O</smiles>

158<smiles>CC1=CC(=O)CC(C)(C)C1CC/C(C)=C/C(=O)O</smiles>

Figure 7. Structures of glycoside derivatives (147-155), enediyne derivatives (156-157) and sesquiterpenes (158-159) from Amycolatopsis.

\subsection{Enediyne Derivatives}

Amycolamycins A (156) and B (157), two new enediyne derivatives, were isolated from Amycolatopsis sp. HCa4, which was collected from locust. Compound 156 could inhibit M231 cell lines by inducing apoptosis through activation of caspase-3 with the $\mathrm{IC}_{50}$ value of $7.9 \mu \mathrm{M}$ [55]. The two enediyne derivatives described above are presented in Figure 7 .

\subsection{Sesquiterpenes}

Two novel abscisic acid-type sesquiterpenes, (E)-3-methyl-5-(2,6,6-trimethyl-3-oxocyclohex1-enyl)pent-2-enoic acid (158) and (E)-3-methyl-5-(2,6,6-trimethyl-4-oxocyclohex-2-enyl)pent- 
2-enoic acid (159), were produced by Amycolatopsis alba DSM 44,262 [31]. However, these two compounds exhibited no antimicrobial activity against $S$. aureus, B. subtilis, P. aeruginosa and C. albicans. The two sesquiterpenes described above are presented in Figure 7.

\section{Biofunction of Amycolatopsis Species}

The Amycolatopsis species have potential for biological degradation, bioconversion and biosorption, which might solve the problem of environmental pollution in the future [68].

\subsection{Biological Degradation}

ZJ0273 was a widely used broad-spectrum herbicide and left in soil in large numbers. Cai et al. found that ZJ0273 could be utilized by Amycolatopsis sp. M3-1 as the sole carbon and energy source with higher degrading activity. At $30^{\circ} \mathrm{C}$ and $\mathrm{pH} 7.0$, the efficiency of ZJ0273 degradation by Amycolatopsis sp. M3-1 was 59.3\% and 68.5\% in 25 and 60 days, respectively [69]. Naproxen was a drug utilized by humans; however, it was detected in surface waters and sanitary effluents in 71 countries, causing toxic effects on biota and further destroying the ecological environment [70]. At the concentration of $50 \mathrm{mg} / \mathrm{L}$, naproxen could be used as the sole carbon and energy source of Amycolatopsis sp. Poz 14 and completely degraded in 18 days, while it will affect the growth of Amycolatopsis when its concentration was more than $50 \mathrm{mg} / \mathrm{L}$ [71]. It takes a long time for plastics to degrade in nature and the resulting environmental pollution problems are becoming more and more serious. Some Amycolatopsis strains possessed a polylactic acid (PLA) degradation capability including Amycolatopsis sp. HT-32, Amycolatopsis sp. 3118, Amycolatopsis sp. KT-s-9, A. mediterranei ATCC 27649, Amycolatopsis sp. 41, Amycolatopsis sp. K104-1, A. orientalis ssp. orientalis, Amycolatopsis thailandensis CMU-PLA07T and Amycolatopsis sp. SCM_MK2-4 [72]. Tan et al. proved that $A$. mediteranei was capable to hydrolyze the aliphatic plastics poly( $\varepsilon$-caprolactone) and poly(1,4-butylene succinate) via a extracellular lipase [73]. In addition, Amycolatopsis sp. ATCC 39,116 could depolymerize high molecular weight lignin species and catabolize a significant portion of the low molecular weight aromatics and may become a mature route for biological lignin valorization in the future [74].

\subsection{Bioconversion}

The strains of Amycolatopsis sp. HR167 and Amycolatopsis sp. ATCC39116 were able to convert ferulic acid (cell wall component of higher plants) into vanillin (important flavor compound) with concentrations of 11.5 and $13.9 \mathrm{~g} / \mathrm{L}$, respectively. The vanillin production of vdh (encoded vanillin dehydrogenase) mutant of Amycolatopsis sp. ATCC39116 was increased 2.3 times due to the enzyme catalyzed the catabolism of vanillin [75]. Wuxistatin, a novel HMG-CoA reductase inhibitor, was transformed from lovastatin by hydroxylase (cytochrome P450) and isomerases of Amycolatopsis sp. CGMCC 1149, showing a four-fold activity, more than lovastatin $[76,77]$.

\subsection{Biosorption}

Albarracín et al. discovered that A. tucumanensis DSM 45,259 (initially named as Amycolatopsis sp. AB0) possessed copper specific biosorption ability $(25 \mathrm{mg} / \mathrm{g})[78,79]$. In the presence of $\mathrm{Cu}(\mathrm{II})$, A tucumanensis DSM 45,259 enhanced the ability of reducing $\mathrm{Cr}(\mathrm{VI})$ [80]. The bioemulsifiers produced by A. tucumanensis DSM 45,259 was able to mediate two times $\mathrm{Cr}(\mathrm{VI})$ recovery compared to deionized water from soil and maybe utilized to recover $\mathrm{Cr}(\mathrm{VI})$ in the future [81]. Baz et al. collected Amycolatopsis sp. GT6, Amycolatopsis sp. GT15 and Amycolatopsis sp. GT39 from abandoned mining areas, which could tolerate high concentrations of metals $(\mathrm{Cu}, 0.1 ; \mathrm{Zn}, 0.1 ; \mathrm{Cr}, 0.15 ; \mathrm{Pb}, 0.25 \mathrm{mg} / \mathrm{mL})$ [82].

\section{Bioactivities of Secondary Metabolites from Amycolatopsis}

The bioactivities of secondary metabolites from Amycolatopsis strains have been also presented in Table 2, including antimicrobial, cytotoxic, antioxidant, topo II $\alpha$ inhibition, anti-hyperglycemic, enzyme inhibition and DNA damage. 
Table 2. The antimicrobial, cytotoxic and other bioactivities of secondary metabolites from Amycolatopsis.

\begin{tabular}{|c|c|c|c|}
\hline Activity Types & Compounds & Bioactivities (MIC, $\mu \mathrm{g} / \mathrm{mL}$ or $\left.\mathrm{IC}_{50}, \mu \mathrm{M}\right)$ & Refs. \\
\hline \multirow[t]{23}{*}{ Antimicrobial activities } & Kigamicins A-E (1-5) & MRSA $(0.03-0.22 \mu \mathrm{M})$ & [13] \\
\hline & Mutactimycin E (16) & $\begin{array}{l}\text { MRSA, S. pneumonia, E. faecium } \\
(1-16 \mu \mathrm{g} / \mathrm{mL})\end{array}$ & [15] \\
\hline & $\begin{array}{l}\text { 7-O-Methyl-5-O- } \alpha \text {-L- } \\
\text { rhamnopyranosylgenestein (20) and } \\
\text { 7-O- } \alpha \text {-D-arabinofuranosyl daidzein }(21)\end{array}$ & $\begin{array}{l}\text { C. albicans, E. coli, MRSA, S. aureus, and } \\
\text { S. typhi }(32-256 \mu \mathrm{g} / \mathrm{mL})\end{array}$ & [18] \\
\hline & Pradimicin-IRD (28) & $\begin{array}{l}\text { S. agalactiae, S. aureus and P. aeruginosa } \\
(3.15 \mu \mathrm{g} / \mathrm{mL})\end{array}$ & [20] \\
\hline & ECO-0501 (42) & MRSA $(0.125-0.25 \mu \mathrm{g} / \mathrm{mL})$ & [24] \\
\hline & Vancoresmycin (48) & MRSA, E. faecium, E. faecalis $(0.05 \mu \mathrm{M})$ & [25] \\
\hline & Amycolatopsins A, C $(\mathbf{4 9}, \mathbf{5 1})$ & $\begin{array}{l}\text { M. bovis }(0.4 \text { and } 2.7 \mu \mathrm{M}) \\
\text { M. tuberculosis }(4.4 \text { and } 5.7 \mu \mathrm{M})\end{array}$ & [26] \\
\hline & Rifamorpholine B (71) & $\begin{array}{l}\text { MRSA, S. aureus, S. pyogenes, B. subtilis, } \\
\text { M. luteus }(0.5-4.0 \mu \mathrm{M})\end{array}$ & [29] \\
\hline & Rifamorpholine D (73) & $\begin{array}{l}\text { MRSA, S. aureus, S. pyogenes, B. subtilis, } \\
\text { M. luteus }(1.0-8.0 \mu \mathrm{M})\end{array}$ & [29] \\
\hline & Macrotermycin A (75) & $\begin{array}{l}\text { B. subtilis, S. aureus, S. cerevisiae, C. } \\
\text { albicans }(1.0-10 \mu \mathrm{g} / \mathrm{mL})\end{array}$ & [29] \\
\hline & Macrotermycin C (77) & $\begin{array}{l}\text { B. subtilis, S. aureus, S. cerevisiae, C. } \\
\text { albicans }(10-25 \mu \mathrm{g} / \mathrm{mL})\end{array}$ & [29] \\
\hline & $\begin{array}{l}\text { Thiazomycin (84) and thiazomycins } \\
\text { A-D }(85,87-89)\end{array}$ & $\begin{array}{l}\text { S. aureus, E. faecalis, S. pneumonia and } \\
\text { their drug-resistant type } \\
(0.002-0.06 \mu \mathrm{g} / \mathrm{mL})\end{array}$ & [31-34] \\
\hline & PRG-A, C $(98,100)$ & $\begin{array}{l}\text { MRSA, E. faecalis, M. luteus, B. subtilis } \\
\qquad(0.72 \mu \mathrm{M})\end{array}$ & {$[37,38]$} \\
\hline & PRG-B, D $(99,101)$ & $\begin{array}{l}\text { MRSA, E. faecalis, M. luteus, B. subtilis } \\
\qquad(5.62-23.37 \mu \mathrm{M})\end{array}$ & [38] \\
\hline & Chloroorienticins A-E (106-110) & $\begin{array}{l}\text { S. aureus JC- } 1 \text { and MRSA } \\
(0.2-0.78 \mu \mathrm{g} / \mathrm{mL})\end{array}$ & [40] \\
\hline & Vancomycin (113) & $\begin{array}{c}\text { S. aureus JC-1 }(0.78 \mu \mathrm{g} / \mathrm{mL}) \text { and MRSA } \\
(1.58 \mu \mathrm{g} / \mathrm{mL})\end{array}$ & [40] \\
\hline & MM 47,761 (115) and MM 49,721 (116) & $\begin{array}{c}\text { B. subtilis ATCC6633, C. xerosis } \\
\text { NCTC9755, M. luteus NCTC8340, S. } \\
\text { aureus, S. saprophyticus FL1, S. } \\
\text { epidermidis 60137, S. pyogenes CN10, S. } \\
\text { agalactiae Hester, S. sanguis ATCC 10556, } \\
\text { S. faecalis I }(0.5-8 \mu \mathrm{g} / \mathrm{mL})\end{array}$ & [41] \\
\hline & Amycophthalazinone A (125) & $\begin{array}{c}\text { S. aureus, S. typhi, C. albicans } \\
(6.92-13.84 \mu \mathrm{M})\end{array}$ & [18] \\
\hline & Echinosporin (134) & $\begin{array}{l}\text { F. oxysporum, F. solani, A. panax, and } P \text {. } \\
\text { herbarum }(32-128 \mu \mathrm{g} / \mathrm{mL})\end{array}$ & [47] \\
\hline & 7-deoxyechinosporin (135) & $\begin{array}{c}\text { F. oxysporum, F. solani, } A \text {. panax, and } P . \\
\text { herbarum }(32-128 \mu \mathrm{g} / \mathrm{mL})\end{array}$ & [47] \\
\hline & Dipyrimicin A (136) & $\begin{array}{l}\text { S. cerevisiae, Kocuria rhizophila, B. subtilis, } \\
\text { Escherichia coli NIHJ, Xanthomonas } \\
\text { campestris pv. oryzae KB } 88 \text { (16-21 mm) }\end{array}$ & [48] \\
\hline & Siderochelin A (139) & $\begin{array}{c}\text { Bacillus pumilus, B. subtilis, E. coli and } S . \\
\text { aureus }(10-15 \mathrm{~mm})\end{array}$ & [50] \\
\hline & Epoxyquinomicins A (143) and B (144) & $\begin{array}{l}\text { M. luteus IFO3333, M. luteus PCI1001 } \\
\qquad(3.12-6.25 \mu \mathrm{g} / \mathrm{mL})\end{array}$ & [51] \\
\hline \multirow[t]{2}{*}{ Cytotoxic activity } & Kigamicin D (4) & $\begin{array}{l}\text { Mouse tumor cell lines } \\
\text { LB32T, L-1210, EL-4, P388D1, B16BL6, } \\
\text { FS3, Colon26 }(0.95 \mu \mathrm{M})\end{array}$ & [13] \\
\hline & $\begin{array}{c}\text { 1-methoxy-3-methyl-8-hydroxy- } \\
\text { anthraquinone } \\
\text { (19) }\end{array}$ & $\begin{array}{c}\text { Lung cancer }(10.3 \mu \mathrm{M}) \\
\text { Lymphoblastic leukemia cells } \\
(16.98 \mu \mathrm{M})\end{array}$ & [17] \\
\hline
\end{tabular}


Table 2. Cont.

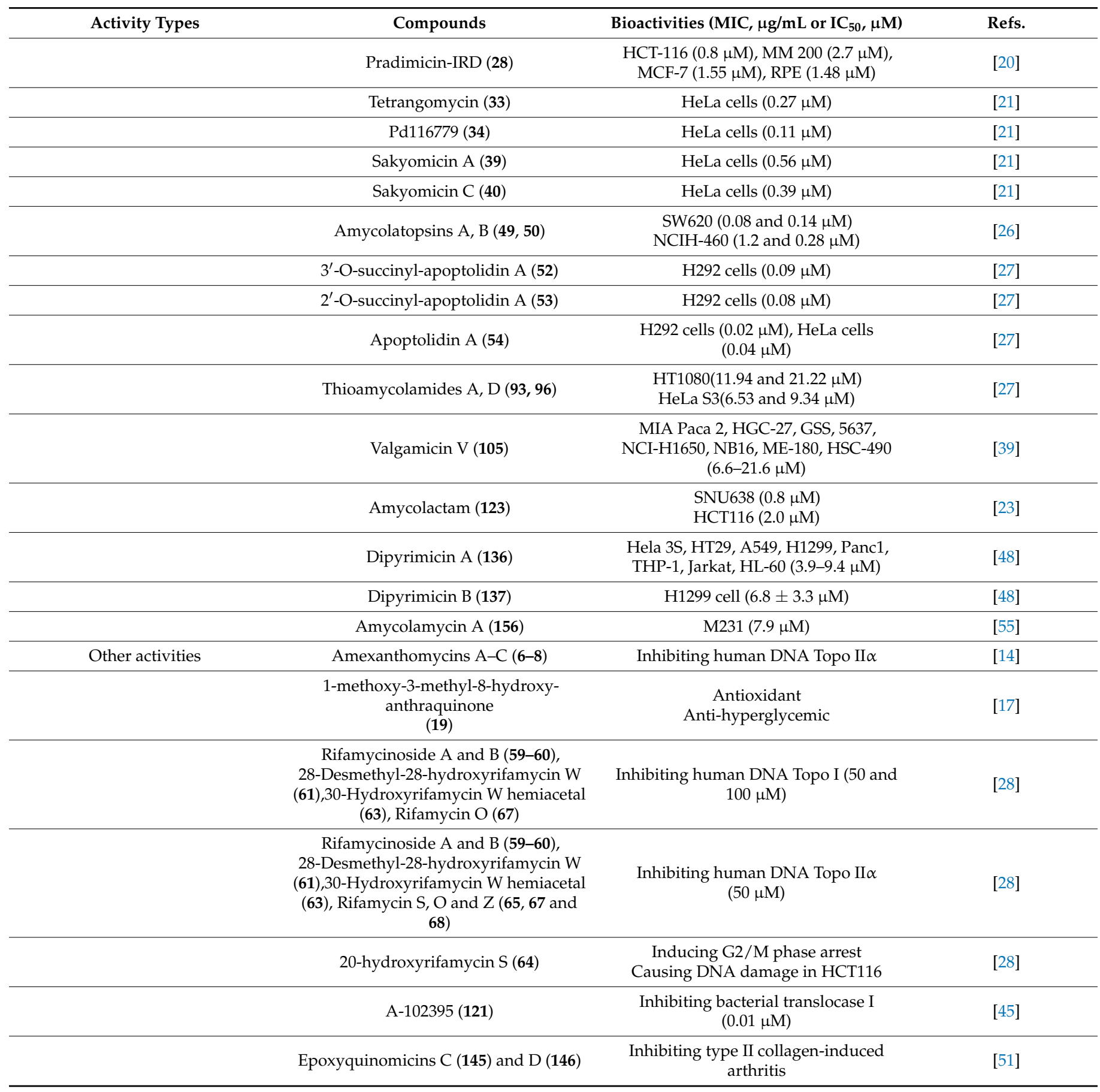

Among the total of 159 secondary metabolites, 41 compounds exhibited potent antimicrobial activities, a majority of which showed inhibition on Gram-positive bacteria growth. Most of them were also found to be active against various multi-drug resistant strains. Kigamicins (1-5), mutactimycin E (16), pradimicin-IRD (28), ECO-0501 (42), vancoresmycin (48), amycolatopsins $A(49)$ and $C$ (51), rifamorpholines $B(71)$ and D (73), macrotermycins $A(75)$ and $C(77)$, thiazomycin (84), thiazomycins A-D (85, 87-89), PRG-A-D (98-101), chloroorienticins A-E (106-110), vancomycin (113), MM 47,761 (115), MM 49,721 (116) and amycophthalazinone A (125) showed significant inhibitory effects against gram-positive bacteria and their drug-resistant types with MIC and $\mathrm{IC}_{50}$ values less than $1 \mu \mathrm{g} / \mathrm{mL}$ and $25 \mu \mathrm{M}$, respectively. While epoxyquinomicins A (143) and B 
(144) displayed moderate activities with MIC values in the range of $3.12-6.25 \mu \mathrm{g} / \mathrm{mL}$. 7-O-Methyl-5-O- $\alpha$-L-rhamnopyranosylgenestein (20), 7-O- $\alpha$-D-arabinofuranosyl daidzein (21), echinosporin (134) and 7-deoxyechinosporin (135) showed modest antibacterial activities with MIC values in the range of $32-256 \mu \mathrm{g} / \mathrm{mL}$.

Of these reported substances, a total of 18 compounds had strong cytotoxicities to different cancer cell lines. For instance, kigamicin D (4) suppressed mouse cancer cell growth, and the $\mathrm{IC}_{50}$ value was approximately $0.95 \mu \mathrm{M}$. 1-Methoxy-3-methyl-8-hydroxyanthraquinone (19) displayed infusive anti-cancer effect on lymphoblastic leukemia together with lung cancer cells, and the $\mathrm{IC}_{50}$ values were 16.98 and $10.3 \mu \mathrm{M}$, respectively. Pradimicin-IRD (28) showed excellent cytotoxicity to HCT-116, MM 200, MCF-7 and $\mathrm{RPE}$ with the $\mathrm{IC}_{50}$ values of $0.8,2.7,1.55$ and $1.48 \mu \mathrm{M}$, respectively. Tetrangomycin (33), pd116779 (34), sakyomicins A (39) and C (40) could inhibit the Hela cells with the $\mathrm{IC}_{50}$ values of $0.27,0.11,0.56$ and $0.39 \mu \mathrm{M}$, respectively. Amycolatopsins A (49) and B (50) had potent effects on resisting human colon cancer (SW620; $\mathrm{IC}_{50}$ values, 0.08 and $0.14 \mu \mathrm{M}$ ) as well as lung cancer (NCIH-460; $\mathrm{IC}_{50}$ values, 1.2 , and $\left.0.28 \mu \mathrm{M}\right)$ cell lines. 3'-O-Succinylapoptolidin A (52), 2'-O-succinyl-apoptolidin A (53) and apoptolidins A (54) could inhibit the $\mathrm{H} 292$ cells with the $\mathrm{IC}_{50}$ values of 91,82 and $22 \mu \mathrm{M}$, respectively. Thioamycolamides A (93) and D (96) showed moderate cytotoxicity to fibrosarcoma HT1080 and cervix adenocarcinoma HeLa with the $\mathrm{IC}_{50}$ values ranging from 6.53 to $21.22 \mu \mathrm{M}$. Valgamicins $\mathrm{V}(\mathbf{1 0 5})$ could inhibit the cancer cells, such as MIA Paca 2, HGC-27, GSS, 5637, NCI-H1650, NB16, ME-180, HSC-490 ( $\left.\mathrm{IC}_{50}, 6.6-21.6 \mu \mathrm{M}\right)$. Amycolactam (123) had marked effect on resisting gastric cancer SNU638 cells as well as colon cancer HCT116 cells. The $\mathrm{IC}_{50}$ values were recorded to be 0.8 and $2.0 \mu \mathrm{M}$, respectively. Dipyrimicin A (136) exhibited moderate cytotoxicity to a series of cancer cells (Hela 3S, HT29, A549, H1299, Panc1, THP-1, Jarkat, HL-60) with the $\mathrm{IC}_{50}$ from 3.9 to $9.4 \mu \mathrm{M}$. However, dipyrimicin B (137) only suppressed the H1299 with the $\mathrm{IC}_{50}$ value of $6.8 \pm 3.3 \mu \mathrm{M}$. Amycolamycin A (156) showed moderate cytotoxicity to M321 with the $\mathrm{IC}_{50}$ value of $7.9 \mu \mathrm{M}$.

A total of 15 compounds showed other bioactivities. Amexanthomycins A-J (6-15) possessed a xanthone-containing pentangular polyphenol core. Compounds 9-15 had no inhibitory effect on DNA topoisomerase II $\alpha$ (Topo II $\alpha$ ), while compounds 6-8 exhibited moderate inhibitory activity against Topo II $\alpha$ at $500 \mu \mathrm{M}$. These results showed that the different numbers and types of deoxysugars in compounds $\mathbf{6 - 1 5}$ will affect the inhibitory activity of topoisomerase. Compound 19 was used at $100 \mathrm{mg} / \mathrm{kg}$ to treat hyperglycemia without inducing any genotoxic effect and also inhibiting $\alpha$-amylase and $\alpha$-glucosidase with the $\mathrm{IC}_{50}$ values of 0.91 and $10.32 \mu \mathrm{M}$, respectively. Experiments in mice have proven the safety and efficacy of compound 19. Compounds 59-61, 63 and 67 exhibited strong activity for inhibiting Topo I at 50 and $100 \mu \mathrm{M}$. Moreover, compounds 59-61, 63, 65, 67 and 68 showed the activity of inhibiting Topo II $\alpha$ at $50 \mu \mathrm{M}$. Compound 64 had strong effect on inhibiting T3SS, resulted in cell cycle arrest at G2/M phase, and led to DNA damage within the HCT116 cells. A-102395 (121) was identified as the strong bacterial translocase I inhibitor, and its $\mathrm{IC}_{50}$ value was $0.011 \mu \mathrm{M}$. At the dose of $1-4 \mathrm{mg} / \mathrm{kg}$, epoxyquinomicins $\mathrm{C}$ (145) and D (146) could inhibit type II collagen-induced arthritis.

\section{Synthesis of Secondary Metabolites from Amycolatopsis and Their Derivatives}

\subsection{Biosynthetic Pathways of Secondary Metabolites from Amycolatopsis}

Research on biosynthetic pathways is essential for the further study on secondary metabolites. For example, finding the regulatory gene could increase or decrease the production of metabolites and also uncover how the concerted efforts of various enzymes to form the compound [83]. In this review, we list the hypothetical biosynthetic pathways for several potent bioactive compounds. Few studies have been conducted and need to arouse the attention of researchers.

The mutant strain A. mediterranei S699 $\Delta$ rifA, which was deleted for the biosynthesis gene of rifamycins, displayed the ability for producing ten new pentangular polyphenols, amexanthomycins A-J (6-15) [14]. As described in the literature, the production of as- 
sociated genes included polyketide synthase (PKS), glycosyltransferase, methyltransferase, monooxygenase, dehydrogenase, oxidoreductase, cytochrome P450 and epimerase (Figure 8A). The biosynthetic pathway of amexanthomycins were proposed by Li et al. [14] and exhibited in the Figure 8B. An acetyl-CoA starter unit and 11 malonyl-CoA extender units could produce prediction intermediate, the pentacyclic xanthone core, by min-PKS synthase, cyclase, and oxidoreductase. Then, the predicted oxidase catalyzed the oxidative rearrangement reaction of intermediate. Finally, this aglycone was glycosylated by the glycosyl transferases, completing the biosynthesis of compounds $\mathbf{6 - 1 5}$ (Figure 8B) [14].

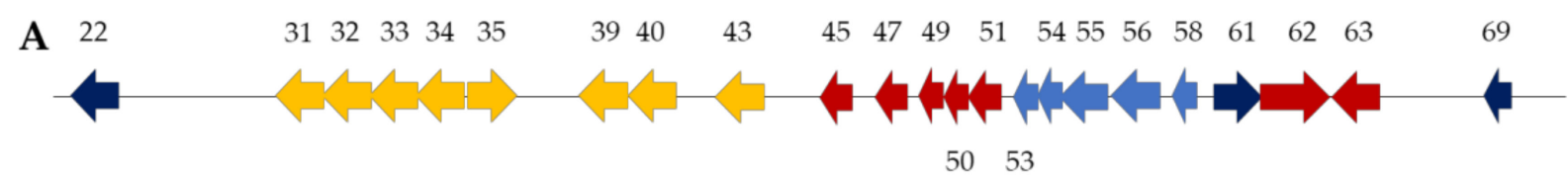

Glycosyltransferase/sugar biosynthesis $\square$ methyltransferase $\square$ PKS

Monooxygenase/ dehydrogenase/oxidoreductase/ cytochromeP450 / epimerase

\section{B}

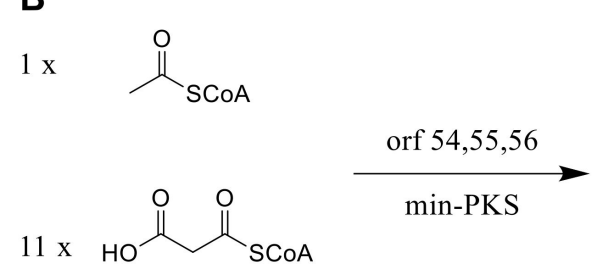

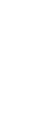<smiles>Cc1c(O)c2c(c(O)c1C(=O)O)-c1c(O)c3c(c(O)c1CC2O)OC1C(O)=CC=CC1C3=O</smiles>

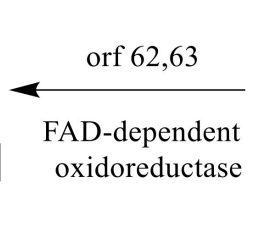<smiles>COc1c2c(c(O)c3c1C(=O)C1C=CC=C(O)C1O3)-c1c(O)c(C(=O)O)c(C)c(O)c1C(O)C2</smiles><smiles>CC(=O)CC(CC(=O)OC(=O)CC(=O)CC(=O)CC(=O)CC(=O)OCC(=O)O)C(=O)O</smiles>

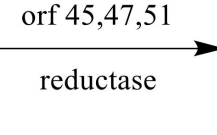<smiles>Cc1c(O)c2c(c(O)c1C(=O)O)-c1c(O)c3c(c(O)c1CC2O)C(=O)C1C=CC=C(O)C1C3=O</smiles>

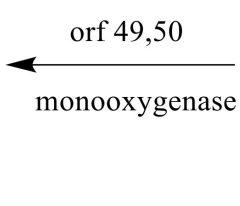<smiles>Cc1cc2c(c(O)c1C(=O)O)C1C=c3cc4cccc(O)c4c(O)c3=CC1CC2</smiles>

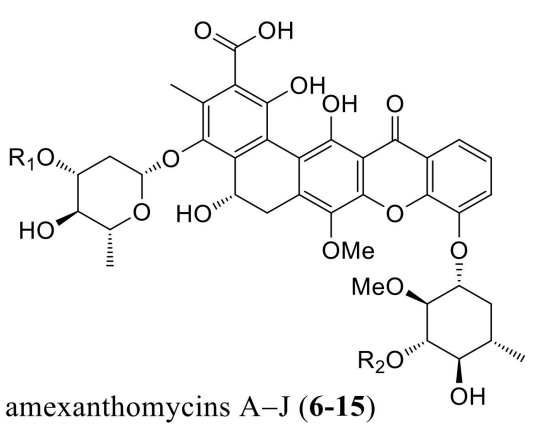

Figure 8. (A) The gene clusters of amexanthomycins A-J. (B) The biosynthetic pathway of amexanthomycins A-J [14].

The genome of $A$. orientalis ATCC 43,491 included a type I PKS which encoded by ORF 18-23 and synthesized the polyketide chain [24]. The monooxygenase and acylCoA ligase were encoded by ORF 7 and 25 which catalyzed arginine to 4-guanidino butyryl-CoA. D-glucose was catalyzed by oxidoreductase (ORF 13) and turned into Dglucuronic acid. Glycine and succinyl-CoA were transformed into 5-aminolevulinate by acyltransferase (ORF 16), and then turned into 5-aminolevulinate-CoA by acyl-CoA ligase (ORF 17). 5-aminolevulinate-CoA was transformed into aminohydroxycyclopentenone 
through cyclization reaction by the coenzyme A ester. Three ORFs (14, 15 and 24) provided glycosyltransferase, amide synthetase and acyltransferase to add 4-guanidino butyryl-CoA, D-glucuronic acid and aminohydroxycyclopentenone onto the polyketide chain which formed compound 47 (Figure 9) [24].<smiles>CCCCCCCCCCCC(N)C(=O)O</smiles>

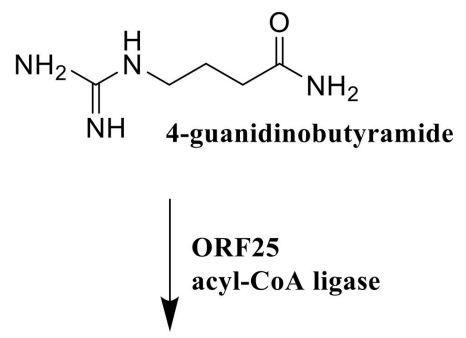<smiles>N=C(N)NCCCC(=O)SO</smiles>

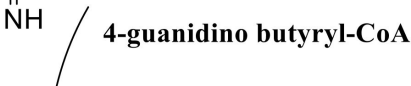

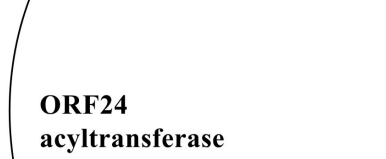
acyltransferase<smiles>OCC1OC(O)C(O)C(O)C1O</smiles>

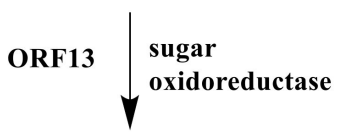<smiles>O=C(O)C1OC(O)C(O)C(O)C1O</smiles>

D -glucuronic acid

ORF14 glycosyltransferase<smiles>NCC(=O)O</smiles>
glycine ORF16 $\downarrow$ acyltransferase<smiles>CCCCCC(=O)CCC(=O)O</smiles>
ORF17 acyl-CoA ligase<smiles>NCC(=O)CCC(=O)O[Na]</smiles>

5-aminolevulinate-CoA O cyclization $\checkmark$<smiles>NC1=C(O)CCC1=O</smiles>

aminohydroxycyclopentenone<smiles>CCCCC(C)C=CCCCC(C)C=C(C)C(O)C(C)CCCCCCCCCC(C)C(=O)O</smiles>

47

Figure 9. The biosynthetic pathway of ECO-0501 (47) [24].

The genome of Amycolatopsis sp. HCa4 was analyzed by antiSMASH and 2ndfind, the cluster 19 was highly similar to the biosynthetic gene cluster of rifamycin [29]. A 3amino-5-hydroxybenzoic acid starter unit and two malonyl CoA and eight methyl malonyl CoA extender units could produce intermediate 1 on a type I polyketide synthase. The release of the polyketide chain and the formation of intramolecular amide were catalyzed by the amide synthase encoded by Rmp F and then generated proansamycin X (intermediate 2). Proansamycin $X$ was then catalyzed by a serious of enzymes encoded by Rmp T, $U$, 11,5 , etc., and turned into the key intermediate 3, dimethyl-desacetyl-rifamycin S. All the above synthetic processes were the same as the synthesis of rifamycin, but Xiao et al. did not find the rifamycin analogs in this strain and they suspected that maybe an unidentified enzyme catalyzed the keto-enol tautomerization of intermediate 3 to form intermediate 4. The intermediate 4 was formed to the intermediate 5 through a crucial 1,6-cyclization, which was further converted into compound 70 and compounds 71-74 followed by two branch pathways. The formation of compound $\mathbf{7 0}$ was catalyzed by $25-\mathrm{O}$-acetyltransferase 
(Rmp 20) and C-27-O-methyltransferase (Rmp 14), as well as epimerization of C-21. However, the formation of compounds 71-74 was not speculated (Figure 10) [29].

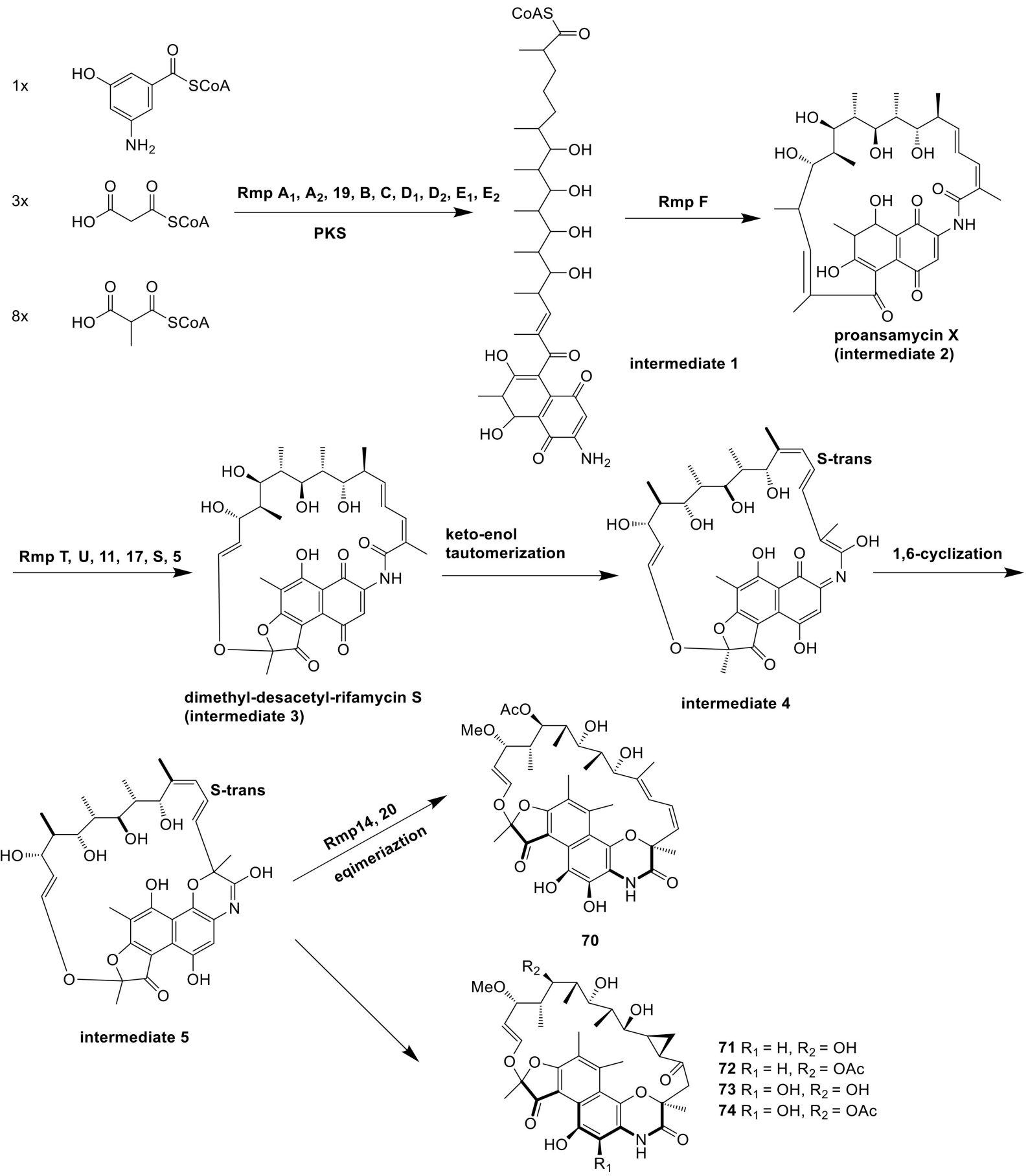

Figure 10. The biosynthetic pathway of rifamorpholines A-E [29].

A-102395 (121) was a capuramycin-type nucleoside antibiotics possessed high specific chemical features, which were isolated from Amycolatopsis sp. SANK 60206. By synthase encoded by $\mathrm{Cpr38}$, chorismate was catalyzed to form 4-amino-4-deoxychorismate (ADC), which subsequently catalyzed elimination of pyruvate by aminotransferase (Cpr12) to form para-aminobenzoic acid (PABA). Catalyzed by actinomycin synthetase (Cpr37), PABA became activated acyl-adenylate and combined with the free-standing carrier protein (Cpr36) to yield the thioester-linked PABA. Under the synergic catalyzation of ketosyn- 
thase (Cpr34) and chain length factor (Cpr35), the thioester-linked PABA as a recipient was decarboxylatively condensed with malonyl-S-acyl carrier protein (ACP) to form $\beta$ ketothioester. That $\beta$-ketothioester was reduced by 3-oxoacyl-ACP reductase Cpr33 and then hydroxylated by luciferase-like monooxygenase Cpr32 to form 3-(4-aminophenyl)2,3-dihydroxypropanoic acid. The next step was polyamide biosynthesis, in which 3(4-aminophenyl)-2,3-dihydroxypropanoic acid was catalyzed by a serious of enzymes including a hydrophilic amino acid (Cpr54), two carrier proteins (Cpr48 and 55), a condensation domain protein (Cpr47), and three transglutaminase-like proteins (Cpr49, 50 and 57) to form an A-102395 core. The coupling of the arylamine-containing polyamide to the A-102395 core was catalyzed by carboxyl methyltransferase (Cpr27) and MitI transacylase (Cpr51) [84]. However, the mechanism of Cpr51 has not been proven and needs further research (Figure 11).

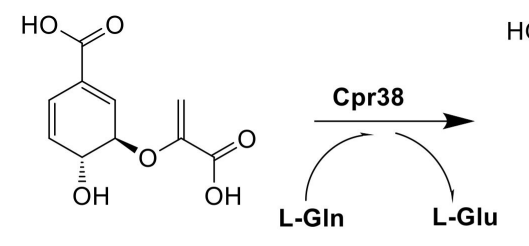

Chorismate<smiles>C=C(OC(O)C(=O)OC1C=C(C(=O)O)C=CC1N)C(=O)O</smiles>

ADC<smiles>Nc1ccc(C(=O)O)cc1</smiles>

PABA

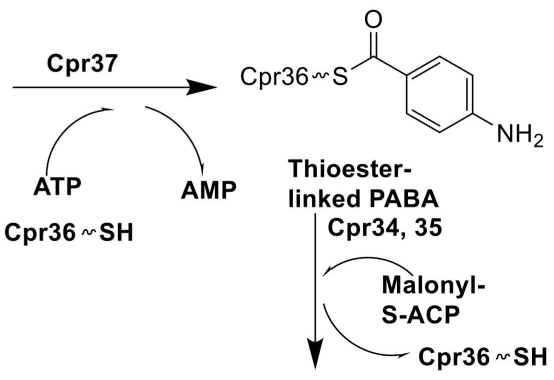

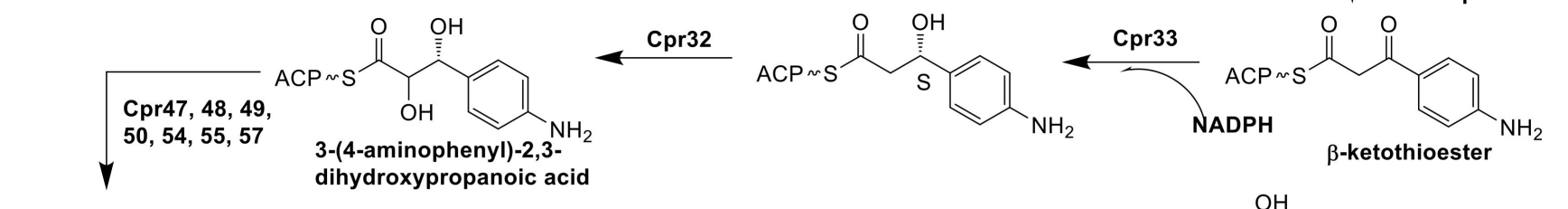

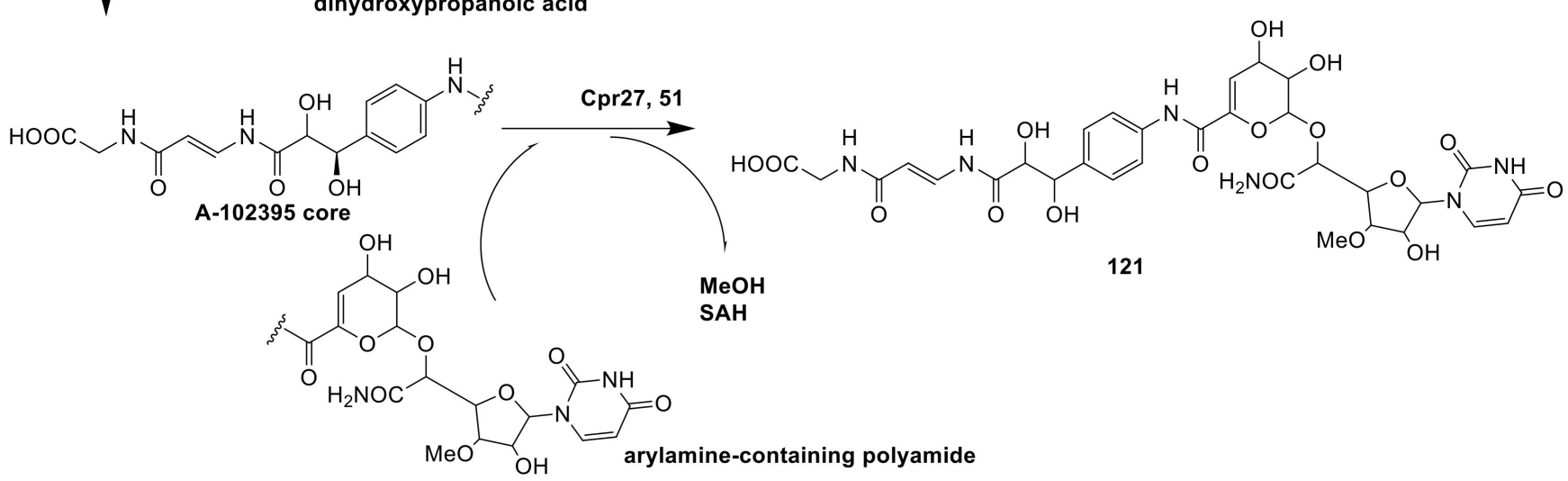

Figure 11. The biosynthetic pathway of A-102395 [84].

The strain Amycolatopsis sp. HCa4 possessed acm gene of amycolamycins A and B, which spanned a $\sim 76 \mathrm{~kb}$ contiguous DNA region. The $\mathrm{Acm}_{2}, \mathrm{~A}_{3}, \mathrm{~A}_{4}$ and $\mathrm{A}_{5}$ provided NDP-glucose dehydrogenase, glucuronic acid decarboxylase, C-methyltransferase and aminotransferase. These enzymes catalyzed the NDP-glucose to NDP activated aminosugar. The 6-methylsalicylic acid synthase, CoA ligase and C-methyltransferase were encoded by $A c m B, B_{2}$ and $B_{1}$, which catalyzed three successive steps starting from acetyl-CoA and malonyl-CoA to 3,6- dimethylsalicylyl CoA. The genes of Acm $\mathrm{P}_{1}, \mathrm{P}_{2}, \mathrm{P}_{3}, \mathrm{P}_{9}, \mathrm{P}_{6}$ and $\mathrm{P}_{4}$ encoded the glycosyltransferase, NRPS A-PCP didomain protein, hydroxylase, monooxygenase, $\mathrm{O}$-methyltransferase and halogenase. These enzymes catalyzed six successive steps converting p-hydroxyphenylpyruvate to 2-chloro-3-hydroxy-4,5-dimethoxymandelate moiety. Acetyl-CoA and malonyl-CoA were catalyzed to form enediyne core by a series of enzymes, which were encoded by $E, E_{2}-E_{11}, D_{2}, L, M$ and $N$. The next step needed $B_{3}$ 
(acetyltransferase) to connect NDP activated aminosugar to 3,6-dimethylsalicylyl CoA. The NDP activated aminosugar and 2-chloro-3-hydroxy-4,5-dimethoxymandelate moiety were then connected to the enediyne core, which needs the Acm $\mathrm{A}_{6}$ (acetyltransferase) and Acm $\mathrm{P}_{10}$ (type II condensation enzyme), respectively. The connection product was transformed into compounds 156 and 157 by bergman cyclization (Figure 12) [55].

(1)

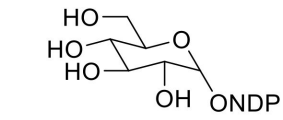

$\left.\begin{array}{l}\text { NDP-glucose } \\ \text { dehydrogenase }\end{array}\right\rfloor A_{2}$

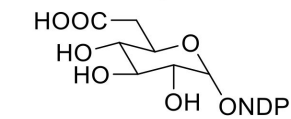

\begin{tabular}{l|l} 
glucuronic acid \\
decarboxylase
\end{tabular} \mid $\mathbf{A}_{3}$<smiles>O=C1COC(O[18OH])C(O)C(O)C1O</smiles>

(2)
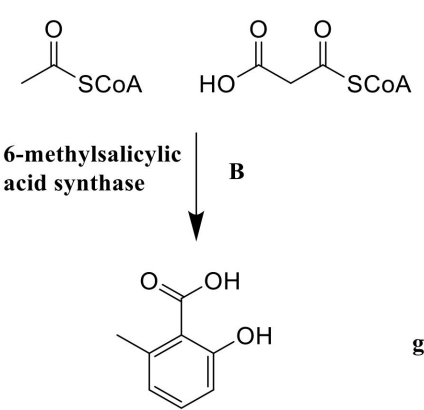

CoA ligase $\downarrow \mathbf{B}_{2}$<smiles>Cc1cccc(O)c1C(=O)O</smiles>

(4)

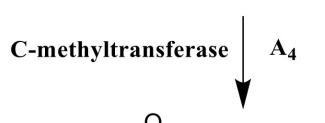<smiles>O=C1OCC2(O)COC1O2</smiles><smiles>C1CCOC1</smiles> 


\subsection{Chemical Synthesis, Semi-Synthesis and Biosynthesis of the Derivatives}

\subsubsection{Chemical Synthesis of DHM2EQ}

DHM2EQ was a derivative of epoxyquinomicin $C$ and possessed greater strong inhibitory activity on type II collagen-induced arthritis than epoxyquinomicin $C$. The derivative was synthesized from 2,5-dimethoxyaniline in 5 steps via chemical synthesis. In pyridine, 2,5-dimethoxyaniline (a) and acetylsalicyloyl chloride were coupled to give salicylamide (b). In methanol, compound (b) was oxidized into quinone monoketal (c) by iodobenzenediacetate. Under deprotection of the phenolic acetyl group, epoxidation of (c) in aqueous THF with alkaline hydrogen peroxide gave epoxide (d). Compound (d) was reduced by $\mathrm{NaBH} 4$ yield (e) and the deprotection of compound (e) with $\mathrm{p}-\mathrm{TsOH}$ gave DHM2EQ (Figure 13) [85].

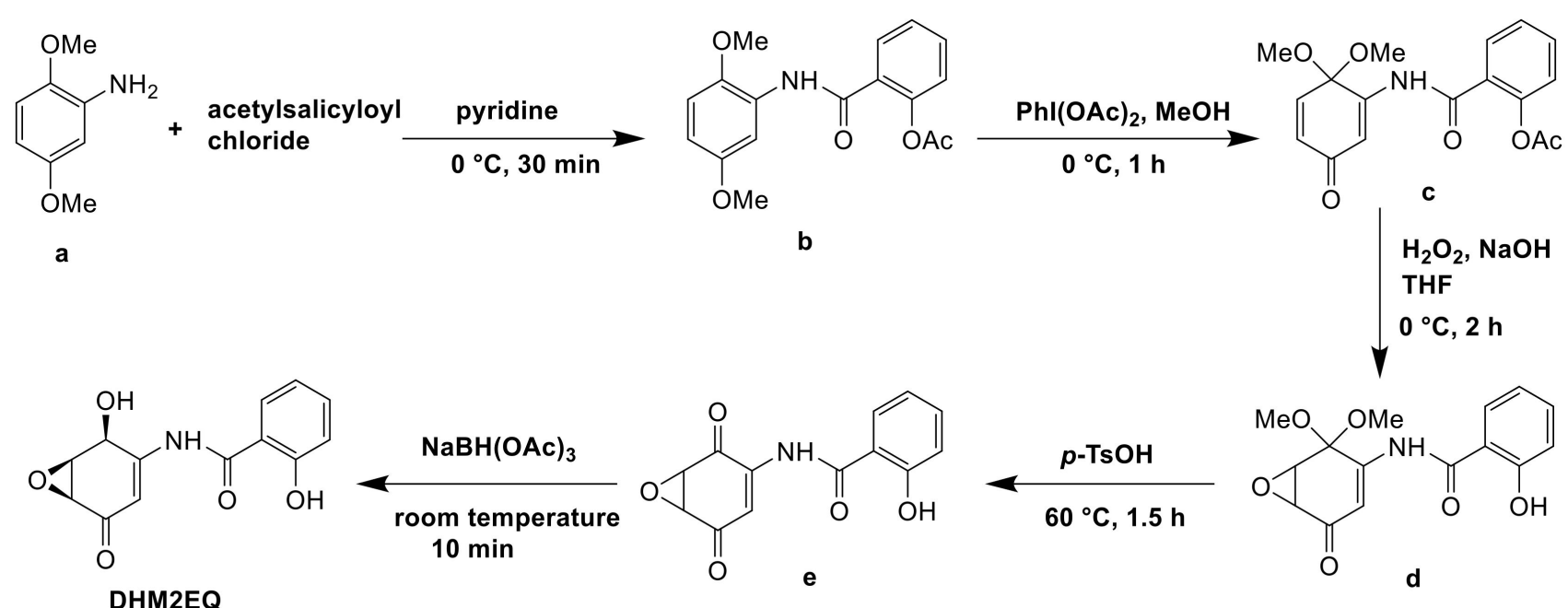

Figure 13. The chemical synthesis pathway of DHM2EQ [85].

\subsubsection{Semi-Synthesis of 24-Desmethylrifampicin}

24-Desmethylrifampicin (d) was a semi-synthetic derivative of rifamycin B and 24desmethylrifamycin B (a) was semi-synthetic precursor of (d). Nigam et al. replaced the acyltransferase domain of module 6 of rifamycin polyketide synthase (rifAT6) with that of module 2 of rapamycin polyketide synthase (rapAT2) to gain a mutant $A$. mediterranei S699 DCO\#34, which could produce 24-desmethylrifamycin B (a). 24-Desmethylrifamycin $\mathrm{S}$ (b) was the oxidation product of compound (a) using $\mathrm{CuCl}_{2}$ as catalyst. Compound (b) was then treated with paraformaldehyde and 1,3,5-trimethyl-hexahydro-1,3,5-triazine in acetic acid to gain 3-methyl-1,3-oxazino(5,6-c)-24-desmethylrifamycin (c), which was subsequently treated with 1-amino-4-methylpiperazine to give 24-desmethylrifampicin (d) [86]. Nirjara et al. uncovered that the damage of RifP, RifQ, transport cascade was an essential reason of the low yield of only $20 \mathrm{mg} / \mathrm{L}$ of compound (a). They thought the production of compound (a) could be increased by blocking RifQ to restore the function of RifP in the future (Figure 14) [87]. 

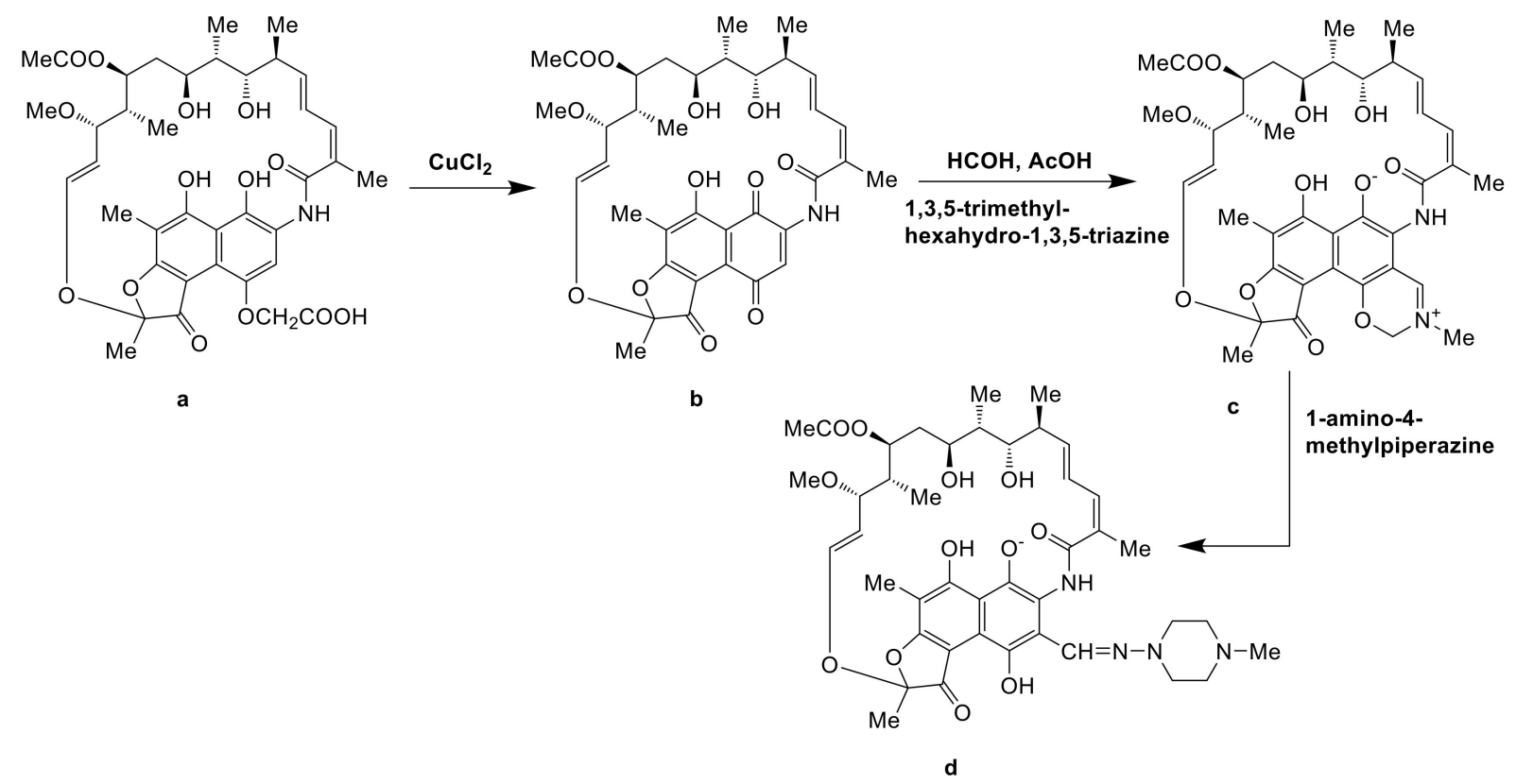

Figure 14. The semi-synthesis pathway of 24-desmethylrifampicin [86,87].

\subsubsection{Biosynthesis of CDCHD}

Chelocardin (CHD) isolated from A. sulphurea was a structurally atypical tetracycline [2]. CHD possessed excellent anti-microbial activity with little toxicity. 2-Carboxamido2-deacetyl-chelocardin (CDCHD) was a derivative of CDH by introducing oxyD (amidotransferase) and oxyP (thiolase) genes from Streptomyces rimosus otc gene cluster into A. sulphurea. The production of CDCHD was very low when only introduced OxyD into A. sulphurea because OxyP could suppress priming of $\mathrm{CDH}$ by removing the competing acetyl units [88]. Then, the CDH gene cluster took over the rest of reaction [89]. These two genes worked together to change the main product from CHD to CDCHD (Figure 15).

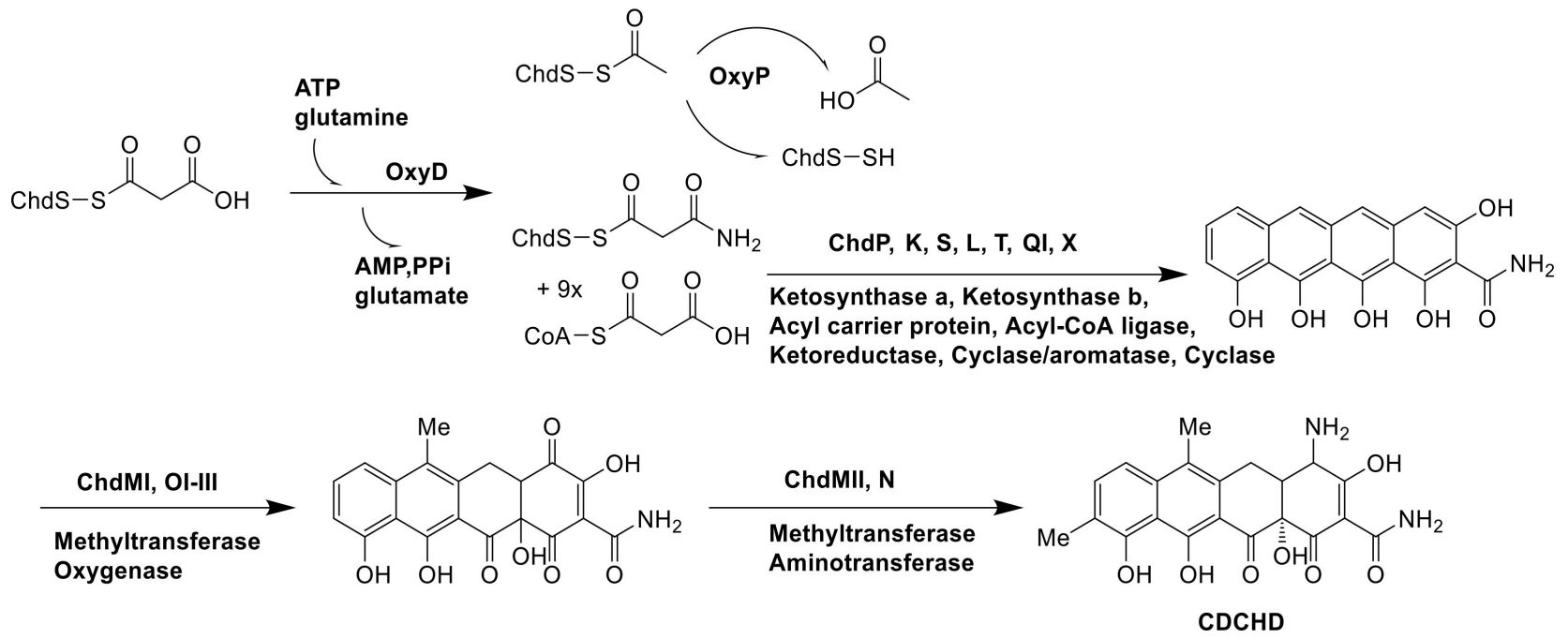

Figure 15. The biosynthesis pathway of CDCHD [88,89].

\section{Conclusions}

This review summarizes the various chemical structures and biological activities of 159 compounds isolated from Amycolatopsis species inhabiting soil, insects, lichen, islands, the marine and plants between 1990-2020. A total of 45 compounds possessed bioactiv- 
ities, of which 32 compounds have glycosides and 31 compounds have cyclic skeletons. Thus, the novel compounds with glycosides and cyclic skeletons should be considered by researchers. For example, compound 51, the homolog of 49 and 50, lacked glycoside and showed 5- to 100-fold less cytotoxicity [26]. The multitudinous secondary metabolites of the genus Amycolatopsis represent great research value and deserve further investigation. On the other hand, the genus of Amycolatosis could metabolize a variety of carbon sources and grow in a wide temperature range, which provides the possibility for them to become important biotechnological tools. It has been proven that this genus has great potential in degrading plastics, treating heavy metals, and biotransformation [68]. More researches are needed to transform these potentials into applications to solve practical problems to benefit mankind.

The study of biosynthetic pathway is a crucial process for excavating bioactive natural products. However, people are more willing to study the biosynthesis and mechanism of action of vancomycin, rifamycin and their derivatives. There are relatively fewer studies on the biosynthesis of other bioactive compounds and more attention is needed to be paid to researchers. In the course of the biosynthetic pathway study, a series of tools, for example, antiSMASH [90] or PRISM [91], have been fully exploited, which could derive a prediction of natural products, including the enzymes, regulatory genes and biosynthetic genes et al. through the genome sequencing results. We could also use these tools to reveal sufficiently more silent biosynthetic gene clusters and uncover more and more new interesting bioactive natural products. The biosynthetic potency of Amycolatopsis species is evidenced to be massive and this genus possesses many silent biosynthetic gene clusters waiting to be found [92]. Recently, Pan et al. obtained two new compounds, amycolapeptins A and B by combined-cultivating two strains of Amycoaltopsis sp. 26-4 and Tsukamurella pulmonis TP-B0596 for the first time, while they could not be discovered in a monoculture of Amycoaltopsis sp. 26-4 [93], which provided a new path for the cultivation of Amycolatopsis.

In conclusion, the research on the genus Amycolatopsis needs to be further considered in-depth. Most of all, the mechanism of action and biosynthetic regulatory genes of potent active compounds deserve to be deeply explored since they could determine the utility value of these compounds. Derivatives sometimes tend to have stronger activity so that more study might be focused on the structural modification of secondary metabolites for providing more analogues to be screened for antibiotics. In addition, compounds with excellent bioactivity that have been discovered should be solved for mass production due to their promising medicinal application. The potential ecological effects of Amycolatopsis species should be also taken seriously. The environmental pollution problem might be solved in some ways by thoroughly excavating the biofunction of the strains. In the future, we firmly believe that the genus Amycolatopsis will show its expansive utilization and serve for pharmaceutical area and environmental protection.

Author Contributions: Z.S. wrote the paper, T.X., J.W., Y.H., C.L. and S.L. checked the paper, S.W. verified the content. All authors have read and agreed to the published version of the manuscript.

Funding: This research was funded by the National Natural Science Foundation of China (No. 81860634), Applied Basic Research Key Project of Yunnan Province (No. 202001BB050029), Major Science and Technology Projects of Yunnan Province (Digitalization, development and application of biotic resource, 202002AA100007), Project of Innovative Research Team of Yunnan Province (202005AE160005), and Science Research Foundation of Yunnan Province Education Department.

Data Availability Statement: All data in this article is openly available without any restrictions.

Conflicts of Interest: The authors declare no conflict of interest.

\section{References}

1. Lazzarini, A.; Cavaletti, L.; Toppo, G.; Marinelli, F. Rare genera of Actinomycetes as potential producers of new antibiotics. Anton. Leeuw. Int. J. Gen. 2000, 78, 399-405. [CrossRef] 
2. Lechevalier, M.P.; Prauser, H.; Labeda, D.P.; Ruan, J.S. 2 New genera of nocardioform Actinomycetes-Amycolata gen. nov and Amycolatopsis gen. nov. Int. J. Syst. Bacteriol. 1986, 36, 29-37. [CrossRef]

3. Stackebrandt, E.; Rainey, F.A.; WardRainey, N.L. Proposal for a new hierarchic classification system, actinobacteria classis. Int. J. Syst. Bacteriol. 1997, 47, 479-491. [CrossRef]

4. Sensi, P.; Greco, A.M.; Ballotta, R. Rifomycin. I. Isolation and properties of rifomycin B and rifomycin complex. Antibiot. Annu. 1959, 7, 262-270. [PubMed]

5. Barna, J.C.; Williams, D.H. The structure and mode of action of glycopeptide antibiotics of the vancomycin group. Annu. Rev. Microbiol. 1984, 38, 339-357. [CrossRef]

6. Preobrazhenskaya, M.N.; Olsufyeva, E.N. Patents on glycopeptides of the vancomycin family and their derivatives as antimicrobials: January 1999-June 2003. Expert. Opin. Ther. Pat. 2004, 14, 141-173. [CrossRef]

7. Harris, C.M.; Kopecka, H.; Harris, T.M. Vancomycin-structure and transformation to Cdp-I. J. Am. Chem. Soc. 1983, 105, 6915-6922. [CrossRef]

8. Bischoff, D.; Pelzer, S.; Bister, B.; Nicholson, G.J.; Stockert, S.; Schirle, M.; Wohlleben, W.; Jung, G.; Sussmuth, R.D. The biosynthesis of vancomycin-type glycopeptide antibiotics-The order of the cyclization steps. Angew. Chem. Int. Edit. 2001, 40, 4688-4691. [CrossRef]

9. Forneris, C.C.; Seyedsayamdost, M.R. In vitro reconstitution of OxyC activity enables total chemoenzymatic syntheses of vancomycin aglycone variants. Angew. Chem. Int. Edit. 2018, 57, 8048-8052. [CrossRef]

10. Li, C.; Liu, X.Q.; Lei, C.; Yan, H.; Shao, Z.H.; Wang, Y.; Zhao, G.P.; Wang, J.; Ding, X.M. RifZ(AMED_0655) is a pathway-specific regulator for rifamycin biosynthesis in Amycolatopsis mediterranei. Appl. Environ. Microbiol. 2017, 83, e03201-16. [CrossRef]

11. Lei, C.; Wang, J.; Liu, Y.; Liu, X.; Zhao, G.; Wang, J. A feedback regulatory model for RifQ-mediated repression of rifamycin export in \&ITAmycolatopsis mediterranei\&IT. Microb. Cell. Fact. 2018, 17. [CrossRef]

12. Chen, S.; Wu, Q.; Shen, Q.; Wang, H. Progress in understanding the genetic information and biosynthetic pathways behind Amycolatopsis antibiotics, with implications for the continued discovery of novel drugs. Chembiochem 2016, 17, 119-128. [CrossRef] [PubMed]

13. Setsuko, K.; Jie, L.; Hiroyasu, E.; Yohko, Y.; Naoko, K.; Yoshiko, H.; Masa, H.; Michiyo, O.; Masaaki, I.; Tomio, T. Kigamicins, novel antitumor antibiotics-I. Taxonomy, isolation, physico-chemical properties and biological activities. J. Antibiot. 2003, 56, $1004-1011$. [CrossRef]

14. Li, X.M.; Wu, X.K.; Zhu, J.; Shen, Y.M. Amexanthomycins A-J, pentangular polyphenols produced by Amycolatopsis mediterranei S699 Delta rifA. Appl. Microbiol. Biotechnol. 2018, 102, 689-702. [CrossRef] [PubMed]

15. Hopp, D.C.; Rabenstein, J.; Rhea, J.; Smith, C.; Romari, K.; Clarke, M.; Francis, L.; Irigoyen, M.; Milanowski, D.; Luche, M.; et al. Mutactimycin E, a new anthracycline antibiotic with gram-positive activity. J. Antibiot. 2008, 61, 675-679. [CrossRef]

16. Kumar, C.G.; Mongolla, P.; Chandrasekhar, C.; Poornachandra, Y.; Siva, B.; Babu, K.S.; Ramakrishna, K.V.S. Anti-proliferative and antioxidant activities of 1-methoxy-3-methyl-8-hydroxy-anthraquinone, a hydroxyanthraquinoid extrolite produced by Amycolatopsis thermoflava strain SFMA-103. Microbiol. Biotechnol. Lett. 2017, 45, 200-208. [CrossRef]

17. Chandrasekhar, C.; Rajpurohit, H.; Javaji, K.; Kuncha, M.; Setti, A.; Ali, A.Z.; Tiwari, A.K.; Misra, S.; Kumar, C.G. Anti-hyperglycemic and genotoxic studies of 1-O-methyl chrysophanol, a new anthraquinone isolated from Amycolatopsis thermoflava strain SFMA-103. Drug. Chem. Toxicol. 2019, 44, 148-160. [CrossRef] [PubMed]

18. Zheng, K.X.; Jiang, Y.; Jiang, J.X.; Huang, R.; He, J.; Wu, S.H. A new phthalazinone derivative and a new isoflavonoid glycoside from lichen-associated Amycolatopsis sp. Fitoterapia 2019, 135, 85-89. [CrossRef]

19. Liu, C.S.; Jiang, Y.; Huang, R.; Jiang, B.G.; Zheng, K.X.; Wu, S.H. Diverse secondary metabolites from a lichen-derived Amycolatopsis Strain. Curr. Microbiol. 2020, 77, 2104-2110. [CrossRef] [PubMed]

20. Bauermeister, A.; Calil, F.A.; Pinto, F.d.C.L.; Medeiros, T.C.T.; Almeida, L.C.; Silva, L.J.; de Melo, I.S.; Zucchi, T.D.; Costa-Lotufo, L.V.; Moraes, L.A.B. Pradimicin-IRD from Amycolatopsis sp. IRD-009 and its antimicrobial and cytotoxic activities. Natl. Prod. Res. 2019, 33, 1713-1720. [CrossRef]

21. Guo, Z.K.; Wang, T.; Guo, Y.; Song, Y.C.; Tan, R.X.; Ge, H.M. Cytotoxic angucyclines from Amycolatopsis sp. HCa1, a rare actinobacteria derived from Oxya chinensis. Planta Med. 2011, 77, 2057-2060. [CrossRef]

22. Guo, Z.K.; Liu, S.B.; Jiao, R.H.; Wang, T.; Tan, R.X.; Ge, H.M. Angucyclines from an insect-derived actinobacterium Amycolatopsis sp. HCa1 and their cytotoxic activity. Bioorg. Med. Chem. Lett. 2012, 22, 7490-7493. [CrossRef]

23. Kwon, Y.; Kim, S.H.; Shin, Y.; Bae, M.; Kim, B.Y.; Lee, S.K.; Oh, K.B.; Shin, J.; Oh, D.C. A new benzofuran glycoside and indole alkaloids from a sponge-associated rare actinomycete, Amycolatopsis sp. Mar. Drugs 2014, 12, 2326-2340. [CrossRef]

24. Banskota, A.H.; McAlpine, J.B.; Sorensen, D.; Ibrahim, A.; Aouidate, M.; Piraee, M.; Alarco, A.M.; Farnet, C.M.; Zazopoulos, E. Genomic analyses lead to novel secondary metabolites. J. Antibiot. 2006, 59, 533-542. [CrossRef] [PubMed]

25. Hopmann, C.; Kurz, M.; Bronstrup, M.; Wink, J.; LeBeller, D. Isolation and structure elucidation of vancoresmycin-A new antibiotic from Amycolatopsis sp ST 101170. Tetrahedron. Lett. 2002, 43, 435-438. [CrossRef]

26. Khalil, Z.G.; Salim, A.A.; Vuong, D.; Crombie, A.; Lacey, E.; Blumenthal, A.; Capon, R.J. Amycolatopsins A-C: Antimycobacterial glycosylated polyketide macrolides from the Australian soil Amycolatopsis sp. MST-108494. J. Antibiot. 2017, 70, 1097-1103. [CrossRef]

27. Sheng, Y.; Fotso, S.; Serrill, J.D.; Shahab, S.; Santosa, D.A.; Ishmael, J.E.; Proteau, P.J.; Zabriskie, T.M.; Mahmud, T. Succinylated apoptolidins from Amycolatopsis sp. ICBB 8242. Org. Lett. 2015, 17, 2526-2529. [CrossRef] [PubMed] 
28. Shi, Y.R.; Zhang, J.L.; Tian, X.Y.; Wu, X.K.; Li, T.H.; Lu, C.H.; Shen, Y.M. Isolation of 11,12-seco-Rifamycin W derivatives reveals a cleavage pattern of the rifamycin ansa chain. Org. Lett. 2019, 21, 900-903. [CrossRef] [PubMed]

29. Xiao, Y.S.; Zhang, B.; Zhang, M.; Guo, Z.K.; Deng, X.Z.; Shi, J.; Li, W.; Jiao, R.H.; Tan, R.X.; Ge, H.M. Rifamorpholines A-E, potential antibiotics from locust-associated actinobacteria Amycolatopsis sp. Hca4. Org. Biomol. Chem. 2017, 15, $3909-3916$. [CrossRef]

30. Beemelmanns, C.; Ramadhar, T.R.; Kim, K.H.; Klassen, J.L.; Cao, S.; Wyche, T.P.; Hou, Y.; Poulsen, M.; Bugni, T.S.; Currie, C.R.; et al . Macrotermycins A-D, glycosylated macrolactams from a termite-associated Amycolatopsis sp. M39. Org. Lett. 2017, 19, 1000-1003. [CrossRef]

31. Li, X.M.; Li, X.M.; Lu, C.H. Abscisic acid-type sesquiterpenes and ansamycins from Amycolatopsis alba DSM 44262. J. Asian Nat. Prod. Res. 2017, 19, 946-953. [CrossRef] [PubMed]

32. Jayasuriya, H.; Herath, K.; Ondeyka, J.G.; Zhang, C.; Singh, S.B. Isolation and structure elucidation of thiazomycin-A potent thiazolyl peptide antibiotic from Amycolatopsis fastidiosa. J. Antibiot. 2007, 60, 554-564. [CrossRef] [PubMed]

33. Zhang, C.; Zink, D.L.; Ushio, M.; Burgess, B.; Onishi, R.; Masurekar, P.; Barrett, J.F.; Singh, S.B. Isolation, structure, and antibacterial activity of thiazomycin A, a potent thiazolyl peptide antibiotic from Amycolatopsis fastidiosa. Bioorg. Med. Chem. 2008, 16, 8818-8823. [CrossRef] [PubMed]

34. Singh, S.B.; Occi, J.; Jayasuriya, H.; Herath, K.; Motyl, M.; Dorso, K.; Gill, C.; Hickey, E.; Overbye, K.M.; Barrett, J.F.; et al. Antibacterial evaluations of thiazomycin-A potent thiazolyl peptide antibiotic from Amycolatopsis fastidiosa. J. Antibiot. 2007, 60, 565-571. [CrossRef]

35. Zhang, C.W.; Herath, K.; Jayasuriya, H.; Ondeyka, J.G.; Zink, D.L.; Occi, J.; Birdsall, G.; Venugopal, J.; Ushio, M.; Burgess, B.; et al. Thiazomycins, thiazolyl peptide antibiotics from Amycolatopsis fastidiosa. J. Nat. Prod. 2009, 72, 841-847. [CrossRef]

36. Pan, C.Q.; Kuranaga, T.; Liu, C.; Lu, S.; Shinzato, N.; Kakeya, H. Thioamycolamides A-E, sulfur-containing cycliclipopeptides produced by the rare Actinomycete Amycolatopsis sp. Org. Lett. 2020, 22, 3014-3017. [CrossRef]

37. Igarashi, M.; Sawa, R.; Kinoshita, N.; Hashizurne, H.; Nakagawa, N.; Homma, Y.; Nishimura, Y.; Akamatsu, Y. Pargamicin a, a novel cyclic peptide antibiotic from Amycolatopsis sp. J. Antibiot. 2008, 61, 387-393. [CrossRef]

38. Hashizume, H.; Sawa, R.; Yamashita, K.; Nishimura, Y.; Igarashi, M. Structure and antibacterial activities of new cyclic peptide antibiotics, pargamicins B, C and D, from Amycolatopsis sp. ML1-hF4. J. Antibiot. 2017, 70, 699-704. [CrossRef]

39. Hashizume, H.; Iijima, K.; Yamashita, K.; Kimura, T.; Wada, S.I.; Sawa, R.; Igarashi, M. Valgamicin C, a novel cyclic depsipeptide containing the unusual amino acid cleonine, and related valgamicins A, T and V produced by Amycolatopsis sp. ML1-hF4. J. Antibiot. 2017. [CrossRef]

40. Tsuji, N.; Kamigauchi, T.; Kobayashi, M.; Terui, Y. New glycopeptide antibiotics. 2. The isolation and structures of chloroorienticins. J. Antibiot. 1988, 41, 1506-1510. [CrossRef]

41. Box, S.J.; Elson, A.L.; Gilpin, M.L.; Winstanley, D.J. MM 47761 and MM 49721, glycopeptide antibiotics produced by a new strain of Amycolatopsis-orientalis-Isolation, purification and structure determination. J. Antibiot. 1990, 43, 931-937. [CrossRef]

42. Berdnikova, T.F.; Shashkov, A.S.; Katrukha, G.S.; Lapchinskaya, O.A.; Yurkevich, N.V.; Grachev, A.A.; Nifant'ev, N.E. The structure of antibiotic eremomycin B. Russ. J. Bioorg. Chem. 2009, 35, 497-503. [CrossRef]

43. Kodani, S.; Komaki, H.; Suzuki, M.; Hemmi, H.; Ohnishi-Kameyama, M. Isolation and structure determination of new siderophore albachelin from Amycolatopsis alba. Biometals 2015, 28, 381-389. [CrossRef]

44. Wu, Q.H.; Deering, R.W.; Zhang, G.Y.; Wang, B.X.; Li, X.; Sun, J.D.; Chen, J.W.; Zhang, H.W.; Rowley, D.C.; Wang, H. Albisporachelin, a new hydroxamate type siderophore from the deep ocean sediment-derived Actinomycete Amycolatopsis albispora WP1(T). Mar. Drugs 2018, 16, 199. [CrossRef]

45. Murakami, R.; Fujita, Y.; Kizuka, M.; Kagawa, T.; Muramatsu, Y.; Miyakoshi, S.; Takatsu, T.; Inukai, M. A-102395, a new inhibitor of bacterial translocase I, produced by Amycolatopsis sp. SANK 60206. J. Antibiot. 2007, 60, 690-695. [CrossRef] [PubMed]

46. Li, X.; Li, X.; Zhu, J.; Wang, H.; Lu, C. Carbamothioic S-acid derivative and kigamicins, the activated production of silent metabolites in Amycolatopsis alba DSM 44262 Delta abm9 elicited by N-acetyl-D-glucosamine. Nat. Prod. Res. 2019, 34, $3514-3521$. [CrossRef]

47. Xu, X.D.; Han, L.; Zhao, L.X.; Chen, X.; Miao, C.P.; Hu, L.F.; Huang, X.S.; Chen, Y.M.; Li, Y.Q. Echinosporin antibiotics isolated from Amycolatopsis strain and their antifungal activity against root-rot pathogens of the Panax notoginseng. Folia. Microbiol. 2019, 64, 171-175. [CrossRef] [PubMed]

48. Izuta, S.; Kosaka, S.; Kawai, M.; Miyano, R.; Matsuo, H.; Matsumoto, A.; Nonaka, K.; Takahashi, Y.; Omura, S.; Nakashima, T. Dipyrimicin A and B, microbial compounds isolated from Amycolatopsis sp. K16-0194. J. Antibiot. 2018, 71, 535-537. [CrossRef]

49. Dasari, V.R.; Muthyala, M.K.; Nikku, M.Y.; Donthireddy, S.R. Novel Pyridinium compound from marine actinomycete, Amycolatopsis alba var. nov. DVR D4 showing antimicrobial and cytotoxic activities in vitro. Microbiol. Res. 2012, 167, 346-351. [CrossRef] [PubMed]

50. Lu, C.H.; Ye, F.W.; Shen, Y.M. Siderochelins with anti-mycobacterial activity from Amycolatopsis sp. LZ149. Chin. J. Nat. Med. 2015, 13, 69-72. [CrossRef]

51. Matsumoto, N.; Tsuchida, T.; Umekita, M.; Kinoshita, N.; Iinuma, H.; Sawa, T.; Hamada, M.; Takeuchi, T. Epoxyquinomicins A, B, $\mathrm{C}$ and D, new antibiotics from Amycolatopsis. 1. Taxonomy, fermentation, isolation and antimicrobial activities. J. Antibiot. 1997, 50, 900-905. [CrossRef] [PubMed] 
52. Breinholt, J.; Kulik, A.; Gurtler, H.; Fiedler, H.P. Tigloside: A new tigloylated tetrasaccharide from Amycolatopsis sp. Acta Chem. Scand. 1998, 52, 1239-1242. [CrossRef]

53. Guo, Z.K.; Jiao, R.H.; Dai, H.F.; Mei, W.L.; Tan, R.X.; Ge, H.M. Actinotetraoses I-K: Tetrasaccharide metabolites produced by an insect-derived Actinobacteria, Amycolatopsis sp. HCa1. Chem. Biodivers. 2013, 10, 296-302. [CrossRef] [PubMed]

54. Guo, Z.K.; Yan, W.; Tan, R.X.; Ge, H.M. Actinotetraose L, a new tetrasaccharide derivative isolated from the mycelia of Amycolatopsis sp. HCa1. J. Asian. Nat. Prod. Res. 2015, 17, 1109-1113. [CrossRef]

55. Ma, S.Y.; Xiao, Y.S.; Zhang, B.; Shao, F.L.; Guo, Z.K.; Zhang, J.J.; Jiao, R.H.; Sun, Y.; Xu, Q.; Tan, R.X.; et al. Amycolamycins A and B, two enediyne-derived compounds from a locust-associated Actinomycete. Org. Lett. 2017, 19, 6208-6211. [CrossRef]

56. Ajila, C.M.; Brar, S.K.; Verma, M.; Tyagi, R.D.; Godbout, S.; Valero, J.R. Extraction and analysis of polyphenols: Recent trends. Crit. Rev. Biotechnol. 2011, 31, 227-249. [CrossRef]

57. Chung, S.; Champagne, E.T. Using phenolic compounds to reduce the allergenic properties of peanut extracts and peanut butter slurries. J. Allergy. Clin. Immunol. 2008, 121, S249. [CrossRef]

58. Lu, J.; Kunimoto, S.; Yamazaki, Y.; Kaminishi, M.; Esumi, H. Kigamicin D, a novel anticancer agent based on a new anti-austerity strategy targeting cancer cells' tolerance to nutrient starvation. Cancer. Sci. 2004, 95, 547-552. [CrossRef]

59. De Almeida, L.C.; Bauermeister, A.; Rezende-Teixeira, P.; dos Santos, E.A.; Beraldo de Moraes, L.A.; Machado-Neto, J.A.; Costa-Lotufo, L.V. Pradimicin-IRD exhibits antineoplastic effects by inducing DNA damage in colon cancer cells. Biochem. Pharmacol. 2019, 168, 38-47. [CrossRef]

60. Butler, M.S.; Buss, A.D. Natural products-The future scaffolds for novel antibiotics? Biochem. Pharmacol. 2006, 71, 919-929. [CrossRef]

61. Kepplinger, B.; Morton-Laing, S.; Seistrup, K.H.; Marrs, E.C.L.; Hopkins, A.P.; Perry, J.D.; Strahl, H.; Hall, M.J.; Errington, J.; Allenby, N.E.E. Mode of action and heterologous expression of the natural product antibiotic vancoresmycin. ACS Chem. Biol. 2018, 13, 207-214. [CrossRef] [PubMed]

62. Griffith, R.S.; Peck, F.B., Jr. Comparative clinical laboratory studies of penicillin V and penicillin G. Antibiot. Annu. 1955, 3, 506-509. [PubMed]

63. Ong, Y.S.; Gao, L.; Kalesh, K.A.; Yu, Z.; Wang, J.; Liu, C.C.; Li, Y.; Sun, H.; Lee, S.S. Recent advances in ynthesis and identification of cyclic peptides for bioapplications. Curr. Top. Med. Chem. 2017, 17, 2302-2318. [CrossRef]

64. Lennard, K.R.; Tavassoli, A. Peptides come round: Using SICLOPPS Libraries for early stage drug discovery. Chem. Eur. J. 2014, 20, 10608-10614. [CrossRef]

65. Hashizume, H.; Adachi, H.; Igarashi, M.; Nishimura, Y.; Akamatsu, Y. Biological activities of pargamicin A, a novel cyclic peptide antibiotic from Amycolatopsis sp. J. Antibiot. 2010, 63, 279-283. [CrossRef]

66. Yushchuk, O.; Binda, E.; Marinelli, F. Glycopeptide antibiotic resistance genes: Distribution and function in the producer Actinomycetes. Front. Microbiol. 2020, 11, 1173. [CrossRef]

67. Matsumoto, N.; Iinuma, H.; Sawa, T.; Takeuchi, T.; Hirano, S.; Yoshioka, T.; Ishizuka, M. Epoxyquinomicins A, B, C and D, new antibiotics from Amycolatopsis. 2. Effect on type II collagen-induced arthritis in mice. J. Antibiot. 1997, 50, 906-911. [CrossRef] [PubMed]

68. Costa, J.S.D.; Amoroso, M.J. Current biotechnological applications of the genus Amycolatopsis. World J. Microbiol. Biotechnol. 2014, 30, 1919-1926. [CrossRef]

69. Cai, Z.Q.; Chen, Q.L.; Wang, H.Y.; He, Y.C.; Wang, W.; Zhao, X.Y.; Ye, Q.F. Degradation of the novel herbicide ZJ0273 by Amycolatopsis sp. M3-1 isolated from soil. Appl. Microbiol. Biotechnol. 2012, 96, 1371-1379. [CrossRef]

70. Der Beek, T.A.; Weber, F.A.; Bergmann, A.; Hickmann, S.; Ebert, I.; Hein, A.; Kuster, A. Pharmaceuticals in the environment-global occurrences and perspectives. Environ. Toxicol. Chem. 2016, 35, 823-835. [CrossRef] [PubMed]

71. Alanis-Sanchez, B.M.; Perez-Tapia, S.M.; Vazquez-Leyva, S.; Mejia-Calvo, I.; Macias-Palacios, Z.; Vallejo-Castillo, L.; Flores-Ortiz, C.M.; Guerrero-Barajas, C.; Cruz-Maya, J.A.; Jan-Roblero, J. Utilization of naproxen by Amycolatopsis sp. Poz 14 and detection of the enzymes involved in the degradation metabolic pathway. World J. Microbiol. Biotechnol. 2019, 35. [CrossRef] [PubMed]

72. Butbunchu, N.; Pathom-Aree, W. Actinobacteria as promising candidate for polylactic acid type bioplastic degradation. Front. Microbiol. 2019, 10, 10. [CrossRef]

73. Tan, Y.; Henehan, G.T.; Kinsella, G.K.; Ryan, B.J. An extracellular lipase from Amycolatopsis mediterannei is a cutinase with plastic degrading activity. Comput. Struct. Biotec. 2021, 19, 869-879. [CrossRef] [PubMed]

74. Salvachua, D.; Karp, E.M.; Nimlos, C.T.; Vardon, D.R.; Beckham, G.T. Towards lignin consolidated bioprocessing: Simultaneous lignin depolymerization and product generation by bacteria. Green Chem. 2015, 17, 4951-4967. [CrossRef]

75. Fleige, C.; Hansen, G.; Kroll, J.; Steinbuchel, A. Investigation of the Amycolatopsis sp. Strain ATCC 39116 vanillin dehydrogenase and its impact on the biotechnical production of vanillin. Appl. Environ. Microbiol. 2013, 79, 81-90. [CrossRef] [PubMed]

76. Zong, H.; Zhuge, B.; Lu, X.Y.; Huo, X.Y.; Fang, H.Y.; Song, J.; Sun, J. Characterization of a novel cytochrome P450 from Amycolatopsis sp. CGMCC1149 for hydroxylation of lovastatin. Biotechnol. Appl. Biochem. 2015, 62, 9-16. [CrossRef]

77. Zong, H.; Zhuge, B.; Fang, H.Y.; Cao, Y.H.; Mu, L.; Fu, W.L.; Song, J.; Zhuge, J. Advances in the bioconversion mechanism of lovastatin to wuxistatin by Amycolatopsis sp. CGMCC 1149. Appl. Microbiol. Biotechnol. 2013, 97, 599-609. [CrossRef] [PubMed]

78. Albarracin, V.H.; Winik, B.; Kothe, E.; Amoroso, M.J.; Abate, C.M. Copper bioaccumulation by the actinobacterium Amycolatopsis sp. ABO. J. Basic Microbiol. 2008, 48, 323-330. [CrossRef] [PubMed] 
79. Albarracin, V.H.; Alonso-Vega, P.; Trujijjo, M.E.; Amoroso, M.J.; Abate, C.M. Amycolatopsis tucumanensis sp. nov., a copper-resistant actinobacterium isolated from polluted sediments. Int. J. Syst. Evol. Microbiol. 2010, 60, 397-401. [CrossRef]

80. Colin, V.L.; Villegas, L.B.; Abate, C.M. Indigenous microorganisms as potential bioremediators for environments contaminated with heavy metals. Int. Biodeter. Biodegr. 2012, 69, 28-37. [CrossRef]

81. Colin, V.L.; Castro, M.F.; Amoroso, M.J.; Villegas, L.B. Production of bioemulsifiers by Amycolatopsis tucumanensis DSM 45259 and their potential application in remediation technologies for soils contaminated with hexavalent chromium. J. Hazard. Mater. 2013, 261, 577-583. [CrossRef]

82. El Baz, S.; Baz, M.; Barakate, M.; Hassani, L.; El Gharmali, A.; Imziln, B. Resistance to and accumulation of heavy metals by actinobacteria isolated from abandoned mining areas. Sci. World J. 2015, 2015, 761834. [CrossRef]

83. Kishimoto, S.; Tsunematsu, Y.; Sato, M.; Watanabe, K. Elucidation of biosynthetic pathways of natural products. Chem. Rec. 2017, 17, 1095-1108. [CrossRef]

84. Cai, W.L.; Goswami, A.; Yang, Z.Y.; Liu, X.D.; Green, K.D.; Barnard-Britson, S.; Baba, S.; Funabashi, M.; Nonaka, K.; Sunkara, M.; et al. The biosynthesis of capuramycin-type antibiotics identification of the A-102395 biosynthetic gene cluster, mechanism of self-resistance, and formation of uridine-5'-carboxamide. J. Biol. Chem. 2015, 290, 13710-13724. [CrossRef]

85. Matsumoto, N.; Ariga, A.; To-e, S.; Nakamura, H.; Agata, N.; Hirano, S.; Inoue, J.; Umezawa, K. Synthesis of NF-k $\beta$ activation inhibitors derived from epoxyquinomicin C. Bioorg. Med. Chem. Lett. 2000, 10, 865-869. [CrossRef]

86. Nigam, A.; Almabruk, K.H.; Saxena, A.; Yang, J.; Mukherjee, U.; Kaur, H.; Kohli, P.; Kumari, R.; Singh, P.; Zakharov, L.N.; et al. Modification of rifamycin polyketide backbone leads to improved drug activity against rifampicin-resistant Mycobacterium tuberculosis. J. Biol. Chem. 2014, 289, 21142-21152. [CrossRef] [PubMed]

87. Singhvi, N.; Singh, P.; Prakash, O.; Gupta, V.; Lal, S.; Bechthold, A.; Singh, Y.; Singh, R.K.; Lal, R. Differential mass spectrometrybased proteome analyses unveil major regulatory hubs in rifamycin B production in Amycolatopsis mediterranei. J. Proteom. 2021, 104168. [CrossRef] [PubMed]

88. Lesnik, U.; Lukezic, T.; Podgorsek, A.; Horvat, J.; Polak, T.; Sala, M.; Jenko, B.; Harmrolfs, K.; Ocampo-Sosa, A.; Martinez-Martinez, L.; et al. Construction of a new class of tetracycline lead structures with potent antibacterial activity through biosynthetic engineering. Angew. Chem. Int. Edit. 2015, 54, 3937-3940. [CrossRef]

89. Lukezic, T.; Lesnik, U.; Podgorsek, A.; Horvat, J.; Polak, T.; Sala, M.; Jenko, B.; Raspor, P.; Herron, P.R.; Hunter, I.S.; et al. Identification of the chelocardin biosynthetic gene cluster from Amycolatopsis sulphurea: A platform for producing novel tetracycline antibiotics. Microbiology 2013, 159, 2524-2532. [CrossRef]

90. Blin, K.; Shaw, S.; Steinke, K.; Villebro, R.; Ziemert, N.; Lee, S.Y.; Medema, M.H.; Weber, T. antiSMASH 5.0: Updates to the secondary metabolite genome mining pipeline. Nucleic Acids Res. 2019, 47, W81-W87. [CrossRef]

91. Skinnider, M.A.; Merwin, N.J.; Johnston, C.W.; Magarvey, N.A. PRISM 3: Expanded prediction of natural product chemical structures from microbial genomes. Nucleic Acids Res. 2017, 45, W49-W54. [CrossRef] [PubMed]

92. Bergeijk, D.A.V.; Terlouw, B.R.; Medema, M.H.; Wezel, G.P.V. Ecology and genomics of Actinobacteria: New concepts for natural product discovery. Nat. Rev. Microbiol. 2020, 546-558. [CrossRef] [PubMed]

93. Pan, C.; Kuranaga, T.; Cao, X.; Suzuki, T.; Dohmae, N.; Shinzato, N.; Onaka, H.; Kakeya, H. Amycolapeptins A and B, cyclic nonadepsipeptides produced by combined-culture of Amycolatopsis sp. and Tsukamurella pulmonis. J. Org. Chem. 2021, 86, 1843-1849. [CrossRef] [PubMed] 